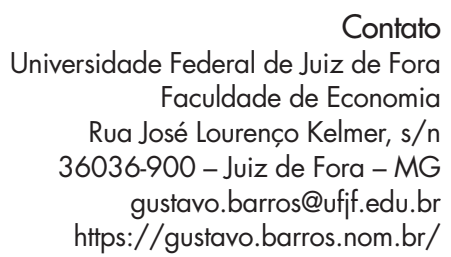

Contato

Universidade Federal de Juiz de Fora Faculdade de Economia Rua José Lourenço Kelmer, s/n 36036-900 - Juiz de Fora - MG gustavo.barros@ufjf.edu.br https://gustavo.barros.nom.br/

\section{DIMENSIONANDO O PROBLEMA SIDERÚRGICO NACIONAL: A DEMANDA POR PRODUTOS SIDERÚRGICOS NO BRASIL (1901-1940)*}

\section{Gustavo Barros**}

Universidade Federal de Juiz de Fora Juiz de Fora - Minas Gerais - Brasil

\title{
Resumo
}

Este artigo examina a demanda por produtos siderúrgicos no Brasil entre 1901 e 1940, levando em consideração a sua dimensão, a sua composição, a sua evolução no tempo, bem como a percepção dos contemporâneos sobre o assunto. Para tanto, o artigo faz uso de abrangente conjunto de fontes primárias, incluindo dados desagregados originais de comércio exterior. A partir dessas fontes, observamos que a dimensão potencial do mercado doméstico exibiu certa estabilidade ao longo das mais de três décadas durante as quais se desenrolou o debate siderúrgico, e que isso se refletiu nas estimativas contemporâneas do tamanho do mercado. Essa relativa estabilidade do tamanho do mercado foi acompanhada por um processo de diversificação da demanda por produtos siderúrgicos.

\section{Palavras-chave}

Siderurgia - desenvolvimento setorial - demanda.

\footnotetext{
Agradeço aos comentários e sugestões de Renato Colistete, de Michel Deliberali Marson, de Fernando Perobelli, dos pareceristas anônimos, assim como dos participantes do V Congresso Latino Americano de História Econômica, do XXI Encontro Nacional de Economia Política, do XVII Seminário sobre a Economia Mineira (Diamantina), do $44^{\circ}$ Encontro Nacional de Economia (Anpec) e dos Seminários em Desenvolvimento Econômico e História da FEA-USP. Durante a pesquisa para meu doutoramento, da qual este trabalho depende substantivamente, contei com o apoio do Conselho Nacional de Desenvolvimento Científico e Tecnológico - CNPq e do Serviço Alemão de Intercâmbio Acadêmico - DAAD, aos quais também agradeço.

"* Doutor em Economia pela Faculdade de Economia, Administração e Contabilidade da Universidade de São Paulo. Professor da Faculdade de Economia e do Programa de Pós-Graduação em Economia da Universidade Federal de Juiz de Fora.
} 


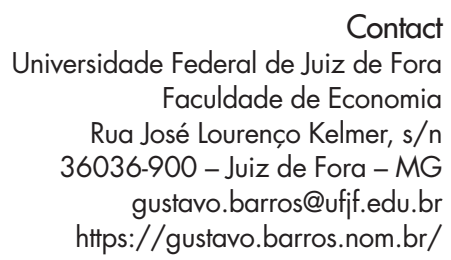

Contact

Universidade Federal de Juiz de Fora Faculdade de Economia Rua José Lourenço Kelmer, s/n 36036-900 - Juiz de Fora - MG gustavo.barros@ufjf.edu.br https://gustavo.barros.nom.br/

\section{ASSESSING THE \\ NATIONAL STEEL- \\ MAKING PROBLEM: \\ THE DEMAND FOR \\ STEEL PRODUCTS IN \\ BRAZIL (1901-1940)}

\author{
Gustavo Barros \\ Universidade Federal de Juiz de Fora \\ Juiz de Fora - Minas Gerais - Brazil
}

\begin{abstract}
This paper examines the demand for steel products in Brazil between 1901 and 1940, considering its dimension, its composition and its evolution, as well as the contemporaries' perception on the issue. In order to do this, a wide array of primary sources is used, including original disaggregated foreign exchange data. Based on these sources, it is observed that the dimension of the potential domestic market exhibited certain stability along the more than three decades during which the steel-making debate took place, and that this reflected on the contemporary estimates of the size of the market. This relative stability of the market size was accompanied by a diversification process of the demand for steel products.
\end{abstract}

\title{
Keywords
}

Steel-making - Brazilian steel industry development - demand. 


\section{Introdução}

Este artigo examina a demanda por produtos siderúrgicos no Brasil entre 1901 e 1940, levando em consideração a sua dimensão, a sua composição e a sua evolução no tempo. Ao longo desse período, o desenvolvimento e a organização do setor siderúrgico brasileiro foram marcados por duas circunstâncias fundamentais. Em primeiro lugar, ao longo desses anos, o setor viveu um importante processo de expansão baseado em empreendimentos privados, ainda que com apoio governamental em muitos casos, mas configurando uma estrutura produtiva algo distinta da que prevaleceria no período posterior - tanto em termos da escala e diversificação da produção, quanto em termos da propriedade das empresas. Em segundo lugar, durante esse período, o Brasil foi palco de um longo e acalorado debate sobre o seu "problema siderúrgico nacional", que seria dado por resolvido apenas com a criação da Companhia Siderúrgica Nacional pelo governo federal em 1941.

O problema siderúrgico nacional tinha, certamente, múltiplas dimensões. No entanto, do ponto de vista material, a questão básica que se colocava era a da insuficiência da oferta doméstica de produtos siderúrgicos para atender as necessidades do país, vale dizer, a sua demanda interna. Ou, posto de outra forma, da precariedade de se depender das importações para esse fim. Muita tinta se gastou sobre o assunto tanto à época quanto posteriormente na historiografia, mas comparativamente pouco se discutiu sobre essa dimensão material, quantitativa, do problema. Não que o assunto não viesse à tona entre os contemporâneos. Vinha, até mesmo com certa frequência, como veremos. Mas uma discussão mais detida a respeito raramente aflorava. A historiografia, por sua vez, deu atenção pouco mais do que superficial à questão. ${ }^{1}$ Reconhecia-se que essa insuficiência da oferta existia e que era

\footnotetext{
1 No tratamento da questão siderúrgica e do longo debate a seu respeito, que se desenrolou entre o final da década de 1900 e o início da década de 1940, destacam-se na historiografia os trabalhos de BAER, Werner. The development of the Brazilian steel industry. Nashville, TN: Vanderbilt University Press, 1969; BAER, Werner. The steel industry. In: BERGSMAN, Joel. Brazil: Industrialization and trade policies. Londres: Oxford University Press, 1970; MARTINS, Luciano. Pouvoir et développement économique: formation et évolution des structures politiques au Brésil. Paris: Antrophos, 1976; SILVA, Edmundo de Macedo Soares e. O ferro na história e na economia do Brasil. Rio de Janeiro: Comissão Executiva Central do Sesquicentenário da Independência do Brasil, 1972; WIRTH, John D. The politics of Brazilian development, 1930-1954. Stanford, CA: Stanford University Press, 1970; RADY, Donald E. Volta Redonda: A steel mill comes to a Brazilian coffee plantation. Albuquerque, New Mexico: Rio Grande Publ., 1973; CALLAGHAN, William Stuart. Obstacles to industrialization: the iron and steel industry in Brazil during the Old Republic. Ph.D. diss., University of Texas at Austin,
} 
um problema. E para sanar esse problema o país precisava da "grande siderurgia". E ponto. Em outras palavras, o problema siderúrgico nacional foi de certa forma tratado como um absoluto.

Esse artigo visa, justamente, preencher essa lacuna, endereçando a questão da dimensão quantitativa do problema siderúrgico nacional. Pretendo dar conta desse objetivo através do tratamento de três aspectos distintos, mas relacionados, da questão. Primeiramente, por intermédio de uma compilação de estimativas contemporâneas da dimensão do mercado doméstico de produtos siderúrgicos ao longo do período. Assim, o artigo examina as intervenções no debate sobre o problema siderúrgico, com destaque para as propostas apresentadas ao governo deste ponto de vista. Em segundo lugar, procuro avaliar a dimensão, a estrutura e a evolução da demanda doméstica por produtos siderúrgicos ao longo do período entre 1901 e 1940. Para tanto, utilizo dados de produção e dados de importação e exportação desagregados previamente indisponíveis na literatura, compilados a partir das estatísticas brutas de comércio exterior do Brasil, procurando estimar o consumo aparente doméstico da forma mais precisa e detalhada possível. Em terceiro lugar, trato da evolução da participação dos produtos siderúrgicos na pauta de importações do país, o que constituía, por si só, um aspecto relevante da dimensão material do problema. Nessa chave, discuto finalmente como a restrição externa influenciou a evolução da forma como os contemporâneos concebiam o "problema siderúrgico nacional", bem como os limites que ela impunha, e impõe, para o dimensionamento do mercado siderúrgico doméstico com os dados disponíveis.

1981; TRINER, Gail D. Mining and the State in Brazilian development. Londres: Pickering \& Chatto Ltd., 2011; BASTOS, Humberto. A conquista siderúrgica no Brasil. São Paulo: Livraria Martins Editora, 1959; GOMES, Francisco M. História da siderurgia no Brasil. Belo Horizonte: Itatiaia, 1983; PELÁEZ, Carlos Manuel. História da industrialização brasileira: Crítica à teoria estruturalista no Brasil. Rio de Janeiro: Apec, 1972; SUZIGAN, Wilson. Indústria brasileira: origem e desenvolvimento. São Paulo: Brasiliense, 1986, p. 256-278; BARROS, Gustavo. O problema siderúrgico nacional na Primeira República. Tese de doutorado, Departamento de Economia, FEA-USP, São Paulo, 2011; e BARROS, Gustavo. Discurso e contexto: política siderúrgica no primeiro governo Vargas (1930-1937), 2014: Disponível em: <https://mpra.ub.uni-muenchen.de/57656/> Dentre estes, os trabalhos de Werner Baer, Edmundo de Macedo Soares e Silva e Gustavo Barros são os mais aprofundados na reconstrução do processo de desenvolvimento do setor siderúrgico no período. 


\section{As estimativas contemporâneas da dimensão do problema siderúrgico nacional}

As pouco mais de três décadas ao longo das quais se estendeu o debate sobre o "problema siderúrgico nacional" foram marcadas por uma verdadeira profusão de propostas e intervenções de empresários, técnicos, especialistas e figuras públicas, tipicamente formuladas por ocasião de determinadas ações no âmbito governamental - quer a promulgação de decretos concedendo favores ao setor, quer discussões públicas em torno de contratos assinados pelo governo, quer chamadas de propostas pelo mesmo. De fato, podemos encontrar na documentação contemporânea intervenções ou propostas com certa regularidade ao longo de todo o período.

Ainda que a questão da dimensão do mercado doméstico e a forma como os contemporâneos estimaram essa dimensão não estejam desligadas - como de resto não poderiam estar - do teor dessas intervenções e propostas, a análise detalhada desse debate foge ao escopo desse trabalho. ${ }^{2}$ Concentraremos aqui nossa atenção nas propostas ou intervenções que tenham procurado estimar quantitativamente o tamanho do mercado doméstico para produtos siderúrgicos - ou, para usar uma expressão frequente à época, as "necessidades do país" em relação a esses produtos. Vista a questão de outro ângulo, tratava-se de avaliar (também) a capacidade de absorção desses produtos pelo mercado doméstico. Essas propostas ou intervenções que continham estimativas desse tipo não são todas, mas elas não deixam de constituir um conjunto representativo.

O levantamento realizado, sumariado no gráfico 1, foi feito com base numa ampla gama de fontes primárias, com destaque para as intervenções e propostas feitas em torno do debate sobre o "problema siderúrgico nacional" ao longo do período. ${ }^{3}$ Essas estimativas incluem todos os documentos con-

\footnotetext{
2 Para uma visão mais geral sobre o debate siderúrgico e sobre as diversas propostas e intervenções feitas no período, ver os trabalhos citados na nota 1.

3 Informações detalhadas sobre os resultados do levantamento podem ser encontradas na tabela A-1 do apêndice. O conjunto de fontes utilizado para os levantamentos aqui consolidados é bastante mais amplo do que os que foram selecionados para análise - vale dizer, do que os que continham alguma estimativa quantitativa da dimensão do mercado doméstico. Os arquivos consultados de forma mais sistemática incluem o Arquivo Nacional (especialmente Fundos do Conselho Nacional de Economia e do Gabinete Civil da Presidência da República), o Centro de Pesquisa e Documentação de História Contemporânea do Brasil (CPDOC) (com destaque para as coleções de Edmundo de Macedo Soares, Getúlio Vargas e Juarez Távora) e a Biblioteca do Ministério da Fazenda no Rio de Janeiro (Biblioteca Domingos Marques Grello).
} 
temporâneos compulsados que cercavam a questão da dimensão do mercado doméstico e que, de duas uma, ou realizavam diretamente essa estimativa ou forneciam informações completas que permitissem o cálculo dela. Apenas estimativas do mercado corrente foram consideradas, não projeções, que serão objeto de discussão adiante. Um total de 37 estimativas pôde ser encontrado cobrindo regularmente, ainda que não homogeneamente, todo o período do debate sobre o problema siderúrgico nacional, que se estendeu de 1909 a 1941 e, mesmo, extravasando um pouco os seus limites.

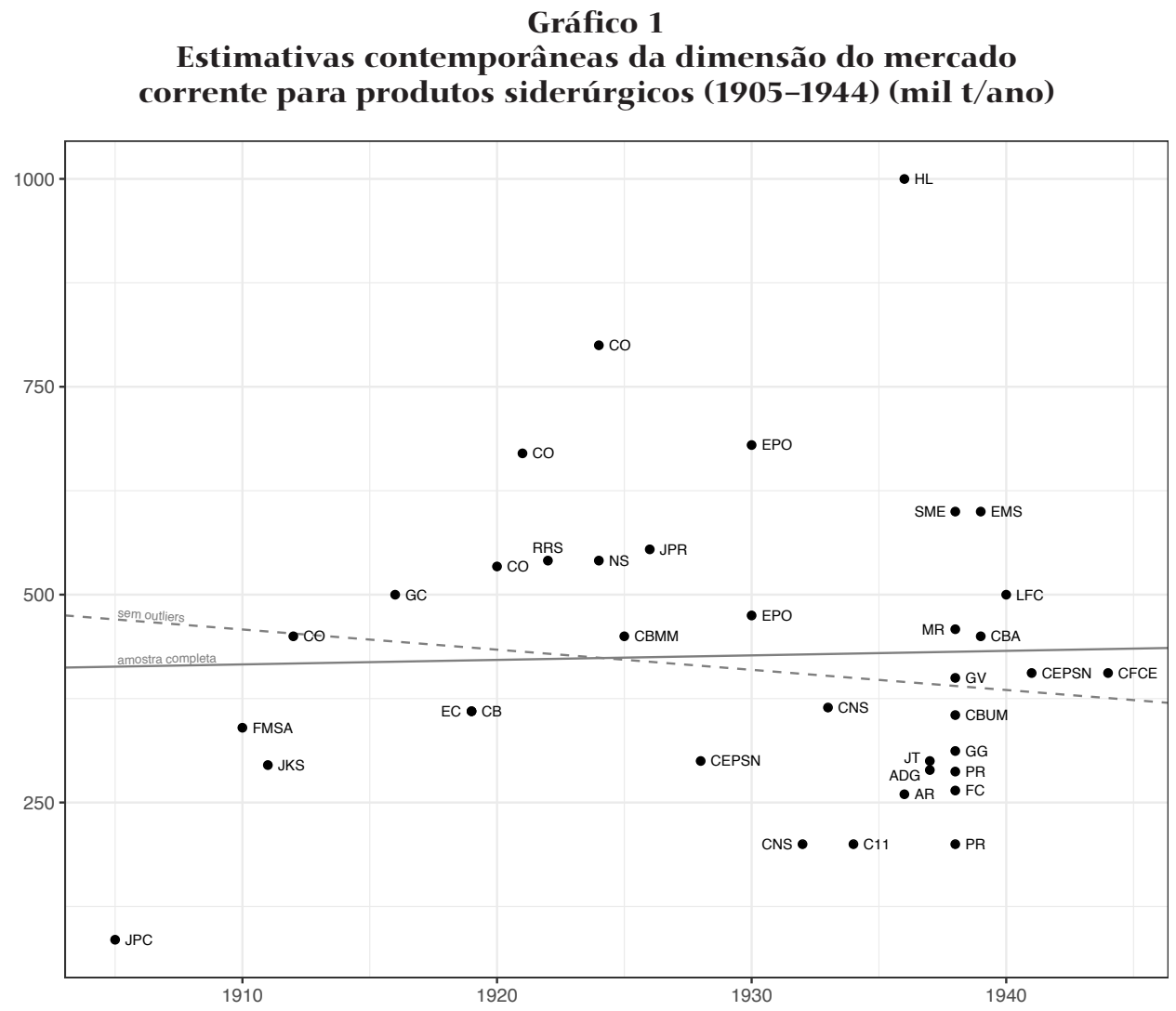

Fontes: A tabela com os dados utilizados, as fontes correspondentes, bem como comentários mais detalhados sobre cada uma das estimativas, incluindo os meios e critérios de estimação e a base de informação utilizada por cada autor e a lista de nomes correspondentes às siglas no gráfico está disponível na tabela A-1 do apêndice.

Para mais detalhes sobre as fontes subjacentes a este levantamento ver BARROS, Gustavo. $O$ problema siderúrgico nacional na Primeira República, op. cit. 
Dois aspectos se destacam na análise dessas estimativas tomadas em conjunto e de sua evolução no tempo. Em primeiro lugar, a sua grande dispersão e, em segundo, a ausência de uma tendência clara de crescimento ao longo do período.

A grande dispersão das estimativas advém de fatores diversos, em boa medida compreensíveis numa amostra como esta. Estimativas realizadas por diversos autores, com interesses e perspectivas diferentes, em diferentes momentos, por distintos meios e usando critérios particulares, tenderiam, inevitavelmente, a gerar resultados divergentes, como geraram de fato. Apesar disso, é possível termos, com base nelas, uma boa ideia da forma como conceberam os contemporâneos a dimensão material do problema siderúrgico nacional. A este respeito, vale notar que 29 das 37 estimativas da amostra estão entre 250 mil t/ano e 600 mil t/ano, o que já delimita a questão numa faixa mais específica. A média geral é de 426,7 mil t/ano.

O segundo aspecto ressaltado acima diz respeito à evolução dessas estimativas contemporâneas ao longo das mais de três décadas ao longo das quais se desenrolou o debate siderúrgico, nomeadamente a ausência de uma tendência clara de crescimento. Essa já é uma proposição que requer uma discussão mais ponderada.

O gráfico 1 apresenta, juntamente com as estimativas contemporâneas da dimensão do mercado doméstico de produtos siderúrgicos, duas linhas de tendência obtidas através de regressão linear. Uma delas (a linha cheia) considera a amostra completa das estimativas apresentadas no gráfico e a outra (a linha pontilhada) considera um subconjunto da amostra, com a exclusão de três estimativas discrepantes. ${ }^{4}$ A linha de tendência da amostra completa apresenta uma inclinação levemente positiva, enquanto a linha de tendência com a exclusão dos outliers apresenta uma inclinação levemente negativa.

Em que pesem os motivos ponderáveis contrários à exclusão de observações discrepantes baseados em critérios puramente estatísticos, no caso das três observações em questão, existem motivos não estatísticos que poderiam justificar a sua exclusão da amostra. Vale observar ainda que a exclusão de qualquer uma dessas três observações individualmente torna o coeficiente de inclinação da reta estimada negativo. Note-se, ademais, que a média das estimativas contemporâneas na década de 1930 foi claramente inferior à das feitas na década de 1920 (405,1 mil t/ano na década de 1930,

\footnotetext{
${ }^{4}$ A seleção dos outliers em questão foi feita com base no método sugerido por GREENE, William H. Econometric analysis. 5a edição. Upper Saddle River, NJ: Prentice Hall, 2003, p. 60-61.
} 
frente a 548,8 mil t/ano na década de 1920) ou mesmo à média das estimativas das décadas de 1910 e 1920 tomadas conjuntamente (478,2 mil t/ano).

Não cabe, porém, exagerar no peso atribuído a essas considerações de ordem estatística que, no caso em pauta, têm claras limitações. Há bons motivos para desconfiarmos da aleatoriedade da amostra, por mais que possamos considerá-la representativa. Já enfatizamos acima também a heterogeneidade dos critérios e métodos utilizados pelos diferentes autores para chegarem às suas estimativas. Do ponto de vista do argumento aqui conduzido, o importante é admitirmos a proposição - já enunciada acima - de ordem mais qualitativa e aproximada, da ausência de uma tendência clara de crescimento das estimativas contemporâneas da dimensão do mercado doméstico de produtos siderúrgicos ao longo do período em consideração, cobrindo mais de três décadas.

Contudo, apesar de justificada, essa proposição nos coloca um problema: ela é francamente contraintuitiva. Afinal, o consumo de produtos siderúrgicos é, na história econômica, tradicionalmente um importante indicador de desenvolvimento, e do desenvolvimento industrial em particular. Tendo isso em vista, como compreender a circunstância de que as estimativas contemporâneas quanto à dimensão do mercado doméstico de produtos siderúrgicos estagnaram ao longo de três décadas, entre as quais as décadas de 1920 e, particularmente, a de 1930, se outros indicadores sugerem o rápido crescimento da economia brasileira no período?

O tratamento mais adequado dessa questão pressupõe o exame das estatísticas subjacentes a estas estimativas, dado de natureza mais objetiva do que estas, que será objeto da próxima seção deste artigo. E envolve ainda, como veremos na quarta seção, também uma discussão a respeito das implicações da restrição externa sobre essas estimativas.

\section{Evolução e estrutura da demanda por produtos siderúrgicos}

A base de informação utilizada na maior parte das estimativas feitas pelos contemporâneos, discutidas na seção anterior, era constituída sobretudo pelas importações de produtos siderúrgicos realizadas pelo país. Ao longo do período, à medida que a produção doméstica foi ganhando maior importância, ela também passou a ser considerada nas estimativas das necessidades do país em relação a esse tipo de produto. O termo "consumo aparente" não chega a ser utilizado nos documentos da época, mas era este o conceito visado por essas estimativas calculadas dessa forma, no caso, definido como "importações + produção doméstica". 
O uso de dados de consumo para estimar a demanda é, evidentemente, uma aproximação. Ao conceito de demanda subjaz a ideia de uma curva que relaciona quantidades demandadas a determinados preços num mercado específico. Os dados de consumo aparente nos oferecem a informação sobre o quanto da demanda teve condições de se efetivar no mercado num dado momento, nas circunstâncias vigentes, circunstâncias estas que incluem os preços correntes, mas não se resumem a eles. Em particular, como veremos adiante, o comportamento do consumo aparente durante o período não esteve sujeito apenas às oscilações de preços, mas foi bastante influenciado por restrições da oferta, particularmente da oferta externa.

Apesar dessas limitações, os dados de consumo aparente são bastante ricos e são particularmente úteis para iluminar um determinado aspecto da demanda que nos interessa especialmente aqui. Podemos chamar de demanda potencial do mercado à quantidade que seria demandada na ausência de restrições da oferta - em particular, em condições normais do setor externo - e em condições de preço que, de alguma forma, sejam consideradas também normais. É o que já viemos chamando anteriormente neste trabalho de tamanho ou dimensão do mercado. E, como veremos, na medida em que a restrição externa gerava um comportamento marcadamente cíclico do consumo de produtos siderúrgicos, são os dados de pico do consumo aparente que nos oferecem a melhor aproximação a esse respeito.

Como é natural, a historiografia sobre o setor siderúrgico brasileiro também fez uso do conceito de consumo aparente - definido daquela forma: "importações + produção doméstica" - como indicador geral da demanda e como base para o cálculo da evolução do coeficiente de importações setorial. O principal exemplo é o trabalho de Werner Baer, que é um dos mais detalhados da literatura em termos de levantamento e compilação de estatísticas históricas sobre o setor no Brasil no período. ${ }^{5}$ Contudo, os dados de Baer, por amplos que sejam, possuem três limitações no que diz respeito ao seu uso para avaliar a dimensão da demanda doméstica por produtos siderúrgicos. ${ }^{6}$

\footnotetext{
BAER, Werner. The development of the Brazilian steel industry, op. cit; BAER, Werner. The steel industry, op. cit.

${ }^{6}$ É justo que se diga que, a meu ver, o principal interesse de Baer era com a evolução do coeficiente de importação, para o que o consumo aparente era uma conta subsidiária. Contudo, essas limitações aqui discutidas também têm, em alguma medida, implicações para as séries de coeficiente de importação.
} 
A primeira delas é que o autor faz uso de séries de importação previamente agregadas e divulgadas pela Fundação Getúlio Vargas. ${ }^{7}$ Baer não especifica o que está sendo agregado em cada uma das séries de importação. No caso do ferro-gusa, há pouca diferença com os dados utilizados neste artigo, mas não no caso das séries "lingotes de aço" e "produtos de aço laminados". Particularmente no que diz respeito à série "lingotes de aço", só é possível presumir que alguns laminados mais simples estavam aí incluídos, pois as importações consignadas nessa série por Baer são claramente superiores às que pudemos obter para "ferro e aço brutos (exceto gusa e fundido)" a partir das estatísticas desagregadas de comércio exterior. Em suma, Baer não trata de garantir a adequada comparabilidade - no sentido de agregarem os mesmos tipos de produtos siderúrgicos - entre as séries de importação e produção, para obter as cifras de consumo aparente.

A segunda limitação é que Baer desconsidera as exportações de produtos siderúrgicos no cálculo do consumo aparente. De fato, uma definição mais rigorosa do consumo aparente seria "produção doméstica + importações - exportações". A hipótese implícita aí - assumida, aliás, por toda a historiografia e por praticamente todos os contemporâneos ${ }^{8}$ - é que essas exportações, no caso brasileiro e no período em questão, eram negligenciáveis. A hipótese é bastante razoável e conduz de fato a uma boa aproximação, mas gera alguma distorção nos resultados a partir do final da década de $1930 .{ }^{9}$

A terceira limitação das estatísticas disponíveis para o setor, entre as quais as de Baer se destacam, diz respeito a uma peculiaridade do setor siderúrgico que gera certas dificuldades na análise do seu comportamento agregado. Isso porque o setor siderúrgico gera três tipos de produtos principais: ferro-gusa, aço e laminados. Os três são de fato produtos do setor, na medida em que são vendidos para outros setores da economia e para a

\footnotetext{
7 BAER, Werner. The development of the Brazilian steel industry, op. cit., p. 61; BAER, Werner. The steel industry, op. cit., p. 205. Não tive acesso direto à fonte de dados dele. De fato, o autor não cita nenhuma publicação específica, diz apenas que são dados da FGV. As críticas que faço a seguir não querem dizer que esses dados tenham, em si mesmos, problemas. Se o objetivo das séries da FGV era simplesmente utilizá-las como indicadores macroeconômicos gerais, elas seriam bastante adequadas para o fim em vista. Na verdade, podemos dizer muito pouco a respeito, na ausência de maiores informações sobre métodos, critérios e utilização dos dados. Contudo, para os objetivos deste artigo, os dados merecem os reparos aqui feitos.

8 A única exceção que conheço é a estimativa da Comissão Executiva do Plano Siderúrgico Nacional, que leva as exportações de ferro-gusa em consideração. Comissão Executiva do Plano Siderúrgico Nacional. Relatório. Rio de Janeiro, 1940-1941, p. 5-9.

9 Ver a tabela A-5 do apêndice.
} 
demanda final, os dois primeiros na forma de produtos fundidos ou noutras formas, e o terceiro diretamente, na forma de produtos laminados. Mas o ferro-gusa e o aço são também importantes insumos para as etapas posteriores de produção: o ferro-gusa é utilizado na produção de aço e o aço na produção de laminados. Além disso, grande parte da produção desses dois produtos destina-se antes ao próprio consumo interno do setor e, mesmo, ao próprio consumo interno de cada empresa do que ao consumo intermediário de outros setores produtivos ou à demanda final. Resultado disso é que, tomadas individualmente, as séries para ferro-gusa, aço ou laminados não são uma boa medida do comportamento agregado do setor - no que diz respeito tanto à produção quanto às importações quanto ao consumo aparente. Por outro lado, a simples soma dessas séries geraria dupla ou mesmo tripla contagem significativa.

Os dados utilizados nesse artigo procuram dar conta dessas limitações na medida em que as séries de importação e exportação foram compiladas a partir dos dados brutos desagregados de comércio exterior e, posteriormente, agregadas tendo em vista a sua adequada comparabilidade com as séries de produção. ${ }^{10}$ Além disso, consideramos aqui as exportações no cálculo do consumo aparente. Por fim, realizamos uma estimativa do consumo intermediário de produtos siderúrgicos pelo próprio setor, o que nos permite o cálculo de uma medida agregada do consumo aparente extrassetorial de produtos siderúrgicos da economia - definido como "produção + importação - exportação - consumo intermediário do setor siderúrgico". Os dados aqui compilados permitem também um exame mais desagregado da composição das importações, o que não era possível com base nas estatísticas previamente disponíveis na literatura. A evolução do consumo aparente extrassetorial ao longo do período em estudo é apresentada no gráfico 2.

\footnotetext{
${ }^{10}$ Estatísticas detalhadas estão disponíveis no apêndice.
} 
Gráfico 2

Consumo aparente extrassetorial de produtos siderúrgicos (1901-1940) (mil toneladas)

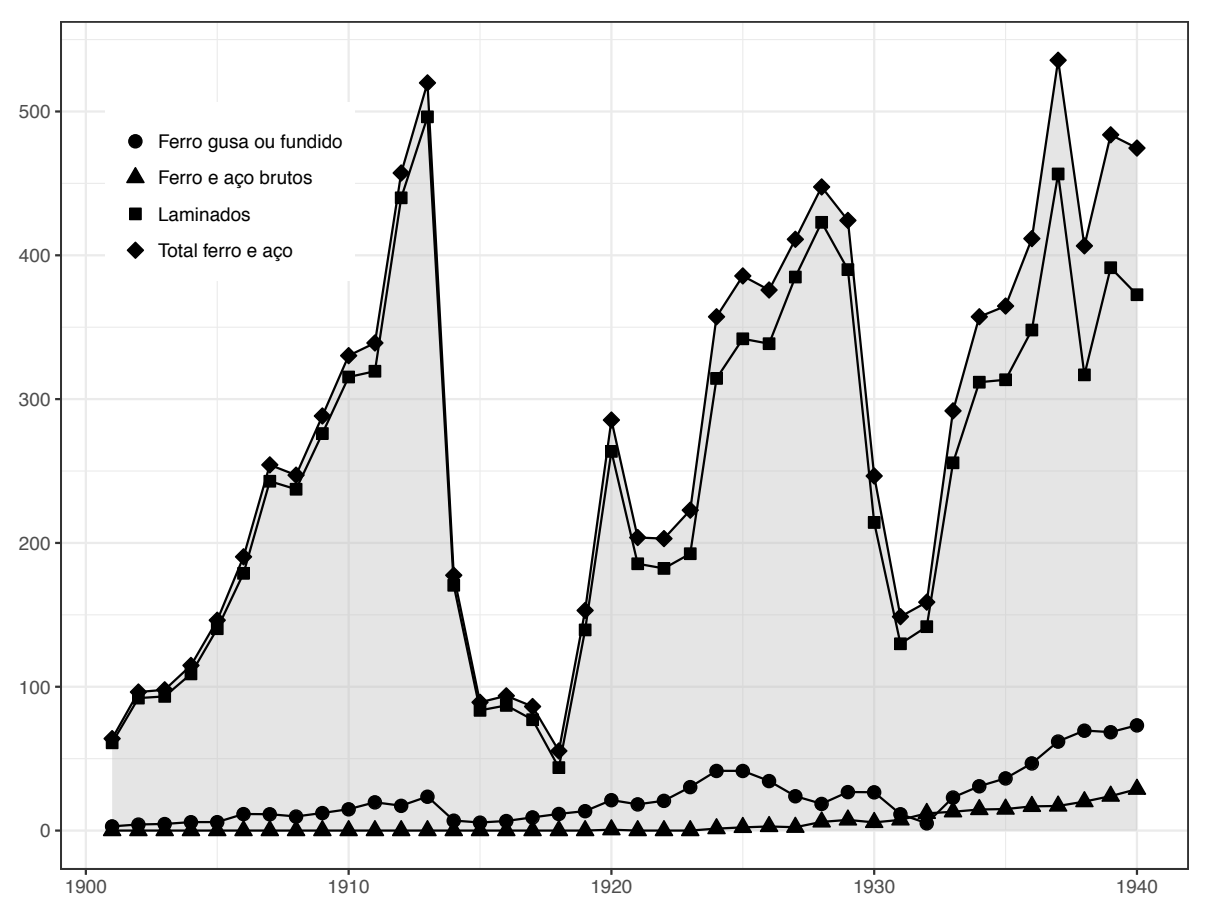

Fonte: Tabela A-2 do apêndice.

Um primeiro aspecto que chama a atenção no comportamento desses dados é que os laminados consistem na maior parte, de longe, do consumo aparente extrassetorial de produtos siderúrgicos. De fato, entre 1901 e 1940, os laminados responderam em média por $90 \%$ do consumo em quantidade e 96\% em valor. Como vemos, havia efetivamente um consumo de ferrogusa e aço na forma de produtos fundidos, mas essa era uma parcela pequena do total. O núcleo do setor siderúrgico - no Brasil, como em outros lugares - residia nos produtos resultantes da conformação mecânica do aço, tipicamente feita por laminação. Os laminados predominam claramente na composição do consumo e da demanda de produtos siderúrgicos. Tendo isso em vista, examinaremos adiante mais detalhadamente a composição das importações de laminados.

Por falta de uma estimativa do consumo de produtos siderúrgicos pelo próprio setor em seu processo de produção e, portanto, de uma medida agregada do consumo de produtos siderúrgicos pelo resto da economia, a historiografia não foi capaz de apreciar apropriadamente essa enorme importância 
dos laminados no problema siderúrgico. Sem dúvida que, dado que se trata de uma cadeia produtiva, é necessário o aço para a produção de laminados e, por sua vez, é necessário o ferro-gusa (normalmente combinado com sucata) para a produção do aço. Contudo, como veremos adiante, particularmente no que diz respeito aos problemas de escala de produção, o não reconhecimento desse predomínio dos laminados na composição da demanda desviou a atenção da historiografia para aspectos menos críticos da questão.

Um segundo ponto a ser destacado a respeito do comportamento do consumo aparente de produtos siderúrgicos ao longo do período é que a sua evolução exibiu movimentos de oscilação de grande amplitude, de acordo com a situação do setor externo. Em momentos em que o setor externo se encontrava numa situação favorável, o consumo crescia e, em conjunturas em que a restrição externa se manifestava, o consumo tendia a se contrair rapidamente. Considerando, como vimos, que a maior parte do consumo de produtos siderúrgicos era composta de laminados e considerando ainda que os coeficientes de importação de laminados continuaram bastante elevados no período, ${ }^{11}$ fica evidente a enorme importância da oferta externa no suprimento da demanda brasileira. Essa relação entre os movimentos do setor externo e as oscilações do consumo aparente de produtos siderúrgicos tem o seu fundamento, portanto, nessa dependência material da oferta externa para o suprimento da demanda interna. Mas, mesmo levando isso em consideração, há que se observar que a amplitude das oscilações era bastante grande, sendo as contrações particularmente abruptas. O caso mais crítico ocorreu durante a Primeira Guerra Mundial: em apenas dois anos, entre 1913 e 1915, a queda do consumo aparente foi de 82,8\%, caindo ainda mais nos anos seguintes, e acumulando uma redução de 89,4\% entre 1913 e 1918.

Há ainda um terceiro aspecto a ressaltar sobre os dados apresentados no gráfico 2. É certo que, como acabamos de observar, ao longo do período como um todo, o consumo aparente extrassetorial de produtos siderúrgicos exibiu três grandes ciclos de expansão e contração. Contudo, apesar dessas amplas oscilações, num determinado sentido, a demanda potencial do mercado de produtos siderúrgicos brasileiro indicada por esses dados possuía certa estabilidade. De fato, a série do consumo aparente extrassetorial de produtos siderúrgicos entre 1901 e 1940 apresenta três picos nos momentos de altas cíclicas: um em 1913, outro em 1927-29 e um terceiro em 1937-40.

\footnotetext{
${ }^{11}$ O coeficiente de importações de laminados em quantidade foi, em 1928, de 92,8\% e, em 1937, ainda era de 82,9\%. O coeficiente em valor, nesses mesmos anos, foi respectivamente de 90,7\% e 86,8\%.
} 
E estes picos têm dimensão bastante próxima, sendo os de 1913 e 1937-40 praticamente equivalentes. Em 1913, o consumo chegou a quase $520 \mathrm{mil}$ t. O segundo momento de alta foi atingido entre 1927 e 1929, tendo sido o consumo de $448 \mathrm{mil} \mathrm{t}$ em 1928. E um novo período de alta ocorreu entre 1937 e 1940, tendo o consumo chegado a 536 mil t em 1937 e ficado em torno das 480 mil t em 1939 e 1940, valor ainda 7,7\% abaixo do pico de 1913. Esse comportamento dos dados teve marcada influência nas estimativas contemporâneas da dimensão do mercado siderúrgico brasileiro. Tipicamente, os períodos de base escolhidos pelos contemporâneos para as suas estimativas recaía nesses picos ou em anos ao redor deles. ${ }^{12}$ Em particular, o pico de 1913 exerceu enorme atração aos que procuraram avaliar o tamanho do mercado doméstico ao longo do restante da década de 1910 e de grande parte da década de 1920.

Esse tipo de seleção não é propriamente arbitrário. Era, como ainda é, bastante plausível atribuir as fortes contrações eventuais do consumo aparente a circunstâncias extraordinárias e, em boa medida, também exógenas. A Primeira Guerra Mundial e a Grande Depressão, sem dúvida alguma, são eventos que podem ser enquadrados nesses termos. A expressão utilizada em 1916 por Gonzaga de Campos para justificar a seleção das estatísticas dos anos pré-guerra em sua estimativa é direta e denota claramente o raciocínio geral empregado por tantos outros. Em seu entender, 1912 e 1913 haviam sido os "últimos anos normais" e é por esse motivo que ele os toma como a referência mais adequada para avaliação da dimensão do mercado doméstico. ${ }^{13}$

Nesse sentido, a melhor forma de compreender a relativa estabilidade - ou, como formulamos acima, a ausência de uma clara tendência de crescimento - das estimativas contemporâneas do tamanho do mercado siderúrgico brasileiro, tomadas em seu conjunto, é justamente observar essa relativa estabilidade dos picos de consumo aparente de produtos siderúrgicos, e a atração que esses anos de pico exerceram sobre as estimativas da época. Tendo isso em vista, e considerando que o pico de 1913 foi algo maior do que o atingido em 1928, fica mais fácil entender também por que - ainda que isso seja algo contraintuitivo - a média das estimativas feitas nos anos 1920 foi claramente maior do que a das estimativas dos anos 1930.

\footnotetext{
12 Ver a tabela A-1 do apêndice.

${ }^{13}$ Informações sobre a industria siderurgica pelo Dr. Gonzaga de Campos, [1916]. Boletim do Serviço Geologico e Mineralogico do Brasil, nº 2, 1922, p. 17.
} 
Na ausência de uma análise global do comportamento do consumo aparente e de um levantamento sistemático das estimativas contemporâneas do tamanho do mercado, como aqui realizados, a historiografia passou ao largo dessa questão. A ideia de que a dimensão do mercado teria permanecido praticamente estável ao longo dos mais de trinta anos durante os quais se desenrolou o debate sobre o problema siderúrgico nacional é estranha à historiografia sobre o tema. Ao contrário, com frequência transparece nela um maior senso de urgência da questão à medida que o debate se alongava, sobretudo a partir da década de 1930, em alguns casos assumindo-se implicitamente a hipótese intuitiva de que isso se dava em função de um consumo crescente de produtos siderúrgicos. ${ }^{14}$ Em parte, a historiografia ecoa com isso a percepção dos contemporâneos que, como veremos adiante, não deixaram de exibir certo otimismo com relação ao potencial desse mercado no país e, durante a década de 1930, viram o problema ganhar relevância não propriamente devido a um aumento percebido da demanda, mas sobretudo em função do agravamento da restrição externa. Com efeito, como teremos ocasião de discutir na próxima seção, as importações de produtos siderúrgicos pesavam cada vez mais no valor total das importações ao longo dessa última década, o que por si só dava à questão uma importância econômica maior do que anteriormente, mesmo que as estimativas do tamanho do mercado, que nos dão a medida da dimensão material do problema, não estivessem crescendo.

No entanto, a despeito dessa relativa estabilidade do tamanho do mercado de produtos siderúrgicos em termos quantitativos, a evolução do consumo desses produtos durante o período em exame era acompanhada de certas mudanças em seu significado. Entre 1901 e 1913, o movimento de expansão do consumo de produtos siderúrgicos ocorreu em circunstâncias favoráveis. A situação do setor externo não apresentava maiores restrições, nem do ponto de vista da balança comercial, nem do lado dos investimentos

\footnotetext{
${ }^{14}$ Esse destaque à década de 1930 como um momento de intensificação dos debates sobre o problema siderúrgico no país é um traço generalizado na historiografia, tipicamente associado às posições mais incisivas sobre a questão siderúrgica adotadas pelo novo governo instalado após a revolução e ao processo de industrialização intensificado pela conjuntura econômica do período. Werner Baer, por exemplo, é explícito em associar a "ansiedade" de Vargas e sua entourage em "promover a construção de uma usina siderúrgica integrada" dado que os produtores existentes "não conseguiam suprir o crescente consumo de produtos pesados de aço de que dependiam as ferrovias, a indústria naval e mesmo uma grande parte da construção civil". BAER, Werner. The development of the Brazilian steel industry, op. cit., p. 64. Em direção similar, ver também WIRTH, John D. The politics of Brazilian development, 1930-1954, op. cit., p. 72; e RADY, Donald E. Volta Redonda: A steel mill comes to a Brazilian coffee plantation, op. cit., p. 116.
} 
estrangeiros. Além disso, a conjuntura era de expansão global da economia brasileira. Na década de 1930, a situação era praticamente a inversa.

Além disso, a estrutura da demanda por produtos siderúrgicos sofreu alguns desenvolvimentos qualitativos importantes ao longo do período em exame que não podem ser devidamente avaliados pelo simples exame do consumo agregado de produtos siderúrgicos. Podemos ter uma visão melhor a respeito com base no gráfico 3 que apresenta a composição das importações de laminados ${ }^{15}$ desagregada entre os seus principais produtos.

\section{Gráfico 3}

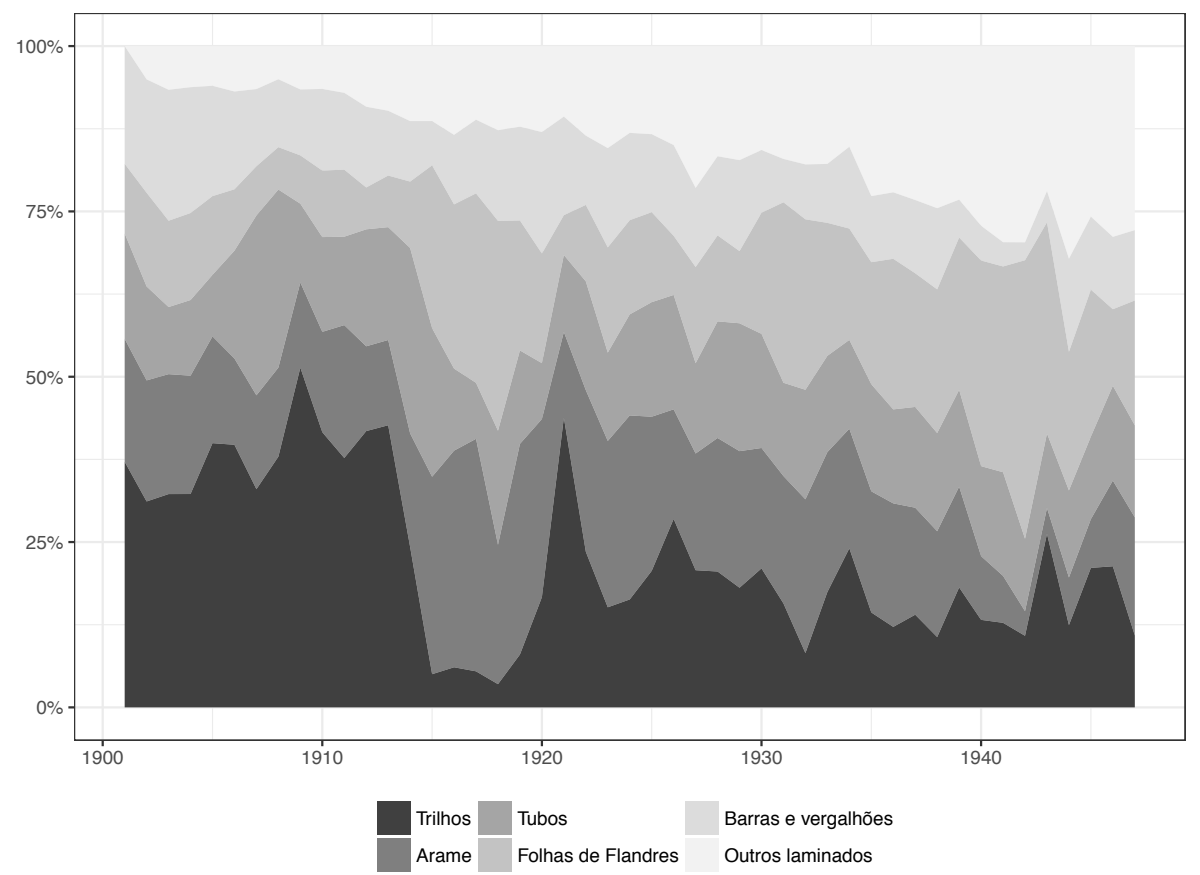

\section{Participação dos principais produtos no valor das importações de laminados (1901-1947)}

Fonte: Tabela A-4 do apêndice.

\footnotetext{
${ }^{15}$ Não possuímos dados desagregados por produto para a produção doméstica de laminados. Mas, na medida em que, como observamos acima, os laminados compunham a maior parte do consumo total de produtos siderúrgicos e que os coeficientes de importação desse tipo de produto eram bastante elevados, o exame da composição das importações de laminados nos dá um bom indicador a respeito.
} 
O gráfico nos mostra que, ao longo do período como um todo, apenas quatro tipos de produtos eram responsáveis pela grande maioria das importações de laminados: trilhos, arame, tubos e folhas de Flandres. Já tivemos a ocasião de observar que os laminados compunham a maior parte do consumo total de produtos siderúrgicos e também que a oferta externa era de grande relevância para o suprimento desses produtos. Tendo isso em vista, o primeiro aspecto a destacar dessa composição é que uma grande parcela das importações de laminados se destinava a usos fora do setor industrial. Os trilhos, em particular, eram o produto individual com mais ampla participação, tendo mesmo, durante o ciclo de expansão das importações de produtos siderúrgicos entre 1901 e 1913, respondido por quase 40\% do valor das importações de laminados. Tubos e arame encontram algum uso industrial, sem dúvida, mas presumivelmente encontravam emprego sobretudo na construção civil e em cercamentos. Entre 1913 e 1940, o arame farpado é responsável por mais da metade da quantidade total de arame importado e, evidentemente, também se pode fazer cerca com arame liso.

No entanto, ao longo do período em exame, a participação da importação de laminados com uso mais claramente industrial sistematicamente aumentou. Embora tenha continuado a ser muito relevante, a participação dos trilhos, por exemplo, reduziu-se significativamente, ficando abaixo dos 20\% no final da década de 1930 (14\% em média entre 1935 e 1939). Inversamente, aumentava a participação das importações de folhas de Flandres e sobretudo as de outros produtos laminados - compostos principalmente por chapas, lâminas e placas, mas também por perfis (cantoneiras, tês etc.), tiras e arcos. Assim, do ponto de vista do setor siderúrgico, o processo de desenvolvimento industrial em andamento no país não se manifestava tanto no volume global de produtos siderúrgicos demandado pela economia, mas sobretudo em alterações na composição da demanda. Portanto, a evolução da demanda ao longo do período correspondia a uma diversificação da sua composição com a manutenção da dimensão agregada, quantitativa, do mercado.

A compreensão dessa evolução em seu conjunto passa por observar que havia um duplo movimento em operação. De um lado, o processo de desenvolvimento industrial e o crescimento global da economia refletiamse numa tendência à expansão da demanda por produtos siderúrgicos e na diversificação de sua composição. De outro lado, a demanda pelo principal produto individual desse tipo de produto - os trilhos - se contraía ao longo do período, em função do arrefecimento do ritmo de crescimento ferroviário depois do seu surto de expansão ocorrido até o início da Primeira Guerra 
Mundial. De fato, a malha ferroviária brasileira cresceu a taxas bem mais lentas a partir de então: entre 1895 e 1915, a extensão da rede ferroviária brasileira cresceu em média 684 km/ano, enquanto, entre 1915 e 1940, a média de expansão foi de menos de metade desse ritmo, ficando em 304 km/ano. ${ }^{16}$ A combinação desses dois fatores responde, em boa medida, por essa evolução de diversificação da demanda com estabilidade da dimensão agregada do mercado que observamos.

Outro aspecto relevante desses dados desagregados é que o confronto entre a composição das importações de laminados e os equipamentos produtivos das empresas siderúrgicas existentes no país, com suas respectivas possibilidades de produção, permite ainda uma avaliação mais qualitativa da insuficiência da oferta doméstica para atender as necessidades do país. ${ }^{17}$ Apesar do ritmo de crescimento que o setor siderúrgico doméstico vinha sendo capaz de sustentar ao longo do período, concretamente ele simplesmente não podia produzir os principais itens laminados que vinham sendo importados. Pelo menos até 1942, a produção de trilhos com maior densidade linear esteve fora das possibilidades produtivas de qualquer empresa em operação no país. A primeira empresa a começar a produção de arame farpado foi a Belgo-Mineira em 1940. Havia empresas que fabricavam tubos, mas apenas tubos feitos por centrifugação de ferro fundido, e não outros tipos de tubos, o que restringia as possibilidades de aplicação da produção doméstica desses produtos. Até meados da década de 1940, nenhuma empresa no país produzia quer chapas, quer folhas de Flandres, quer perfis que não os mais leves. Portanto, o gargalo produtivo do setor, tanto quantitativa quanto qualitativamente, residia na produção de laminados. Ou seja, apesar do desenvolvimento do setor desde a década de 1920, uma das principais

\footnotetext{
${ }^{16}$ Calculado a partir de dados de SAES, Flávio Azevedo Marques de. As ferrovias de São Paulo, 18701940. São Paulo: Hucitec, 1981, p. 24. Flávio Saes trata detalhadamente do processo de declínio das principais estradas de ferro paulistas durante o período (ver, em particular, p. 29, 49-54). Para uma fundamentada reconstrução desse processo de redução do ritmo de crescimento ferroviário do ponto de vista do também importante caso mineiro, ver BATISTA, Felipe Alvarenga; BARBOSA, Lidiany Silva; GODOY, Marcelo Magalhães. Transportes, modernização e formação regional - Subsídios à história da era ferroviária em Minas Gerais, 1870-1940. Revista de História Regional, vol. 17, n. 1, 2012, p. 162-203.

${ }_{17}$ Para uma descrição detalhada das empresas existentes e criadas no período em análise, bem como das suas possibilidades produtivas, ver BARROS, Gustavo. O desenvolvimento do setor siderúrgico brasileiro entre 1900 e 1940: Criação de empresas e evolução da capacidade produtiva. Revista de História Econômica e Economia Regional Aplicada (Heera), vol. 8, n. 14, jan-jun 2013; e SILVA, Edmundo de Macedo Soares e. O ferro na história e na economia do Brasil, op. cit., p. 85-89.
} 
limitações do setor siderúrgico nacional para atender às necessidades do país consistia na insuficiente diversificação dos produtos que era capaz de produzir. Ainda no início da década de 1940, os tipos de produtos laminados que compunham a maior parcela do consumo simplesmente não podiam ser supridos pelo setor produtivo doméstico.

Agravava essa situação a circunstância de que uma consequência do processo de diversificação da composição da demanda por produtos siderúrgicos com a manutenção da dimensão global do mercado, que observamos acima, é que a escala de produção dos produtos finais individuais que o mercado nacional era capaz de absorver tornava-se correspondentemente menor. Claro, existe uma relação entre, por um lado, o volume global de produção e o tamanho do mercado e, por outro, a diversificação que é possível ao setor oferecer, operando através da escala econômica de produção. Essa articulação e os problemas a ela associados não passaram despercebidos aos contemporâneos. Em que pese todo o alarde em torno da "grande siderurgia" no país ao longo do período, mesmo então era claro que o mercado doméstico não comportava sequer uma única usina de grandes dimensões, se por grandes dimensões se entendessem os padrões internacionais à época. De fato, já em 1910, o general Francisco M. de Souza Aguiar foi enviado por Nilo Peçanha ao exterior para observar métodos e técnicas de produção do setor siderúrgico nos Estados Unidos e na Europa, tendo se preocupado, em particular, com a capacidade de produção das maiores usinas dos principais países produtores. ${ }^{18}$ Segundo o seu relatório, as grandes usinas internacionais à época distribuíam-se numa faixa que girava em torno de 500 mil t/ano a 2,5 milhões de t/ano, ${ }^{19}$ isto é, grosso modo de uma a cinco vezes o tamanho do mercado brasileiro inteiro de produtos siderúrgicos que, como vimos, permaneceu em torno das 500 mil t/ano ao longo das três décadas seguintes. Em outras palavras, a situação que se configurava para o setor no país era a de um monopólio natural.

É certo, porém, que essas grandes usinas internacionais não eram o melhor ponto de comparação para avaliar as possibilidades de operação, em escala suficientemente econômica, mesmo que não a mais econômica, de uma usina no Brasil. Mesmo nos mercados consolidados, existiam usinas

\footnotetext{
${ }^{18}$ AGUIAR, Francisco M. de Souza. A industria siderurgica: Relatorio apresentado ao exmo. sr. presidente da Republica pelo general F. M. de Souza Aguiar. Rio de Janeiro: Imprensa Nacional, 1910.

${ }_{19}$ Para as capacidades das diversas usinas por ele referidas, ver Idem, op. cit., p. 82, 110-111, 160, $162,165,167,170,175$.
} 
menores - em alguns casos com uma produção mais especializada, mas nem sempre - e que conviviam com essas grandes num mesmo mercado. Raul Ribeiro da Silva ressaltou esse ponto no início da década de 1920. Segundo ele, das 242 fábricas existentes no setor nos Estados Unidos em 1916, cerca de 160 não atingiam as 500 mil t/ano de produção. ${ }^{20}$ Ademais, alguma margem nos diferenciais de custo de produção devido à menor escala produtiva poderiam ser compensados por outros fatores de ordem local, como os custos de transporte e mesmo os custos dos insumos e dos fatores de produção. ${ }^{21}$

Ainda assim, a dimensão do mercado doméstico, relativamente à escala de produção econômica do setor, impunha limites concretos às possibilidades de expansão e organização da produção siderúrgica no país. Essa circunstância gerava, por exemplo, um trade-off entre a escala de produção e o combate ao (potencial) poder de mercado das empresas do setor. Durante as discussões na década de 1910, as opiniões parecem ter tendido a sacrificar a escala de produção em favor de uma maior competição entre os produtores domésticos. ${ }^{22}$ De fato, muito das críticas à concessão feita em dezembro de 1910 aos empresários Carlos Wigg e Trajano de Medeiros dirigiu-se à extensão dos mesmos favores a outras empresas "para evitar o monopólio". O que se vislumbrava então era a divisão do mercado entre três empresas com capacidade de 150 mil t/ano cada uma. Já ao final da década de 1930, a questão da escala de produção passou a pesar mais na balança. As propostas que gozaram de maior influência nesse período convergiam para a ideia de complementar o parque produtivo doméstico - que havia crescido significativamente desde 1910, atingindo então uma capacidade produtiva em torno de 180 a $200 \mathrm{mil} \mathrm{t} / \mathrm{ano}^{23}$ - com a construção de uma única usina de capaci-

\footnotetext{
${ }^{20}$ SILVA, Raul Ribeiro da. O problema da siderurgia no Brasil e o contracto da Itabira Iron Ore Company Limited. Rio de Janeiro, 1922, p. 31-34. Ele acrescenta ainda: "Com mais detalhe, diremos que, dessas 242 fabricas, apenas 10 produziram mais de 1 milhão de toneladas; 9 produziram de 500 a 1 milhão, 88 de 100 a 500.000 e 77 dessas fábricas produziram menos de 100.000 toneladas durante aquele ano" (p. 31). Infelizmente, a soma dele não fecha, e de maneira que é difícil saber onde está o equívoco. Em todo caso, as 77 mais as 88 dos dois estratos de usinas menores se aproximam das "cerca de 160" mencionadas.

${ }^{21}$ Raul Ribeiro da Silva não as menciona, mas evidentemente os fatores incluem também as tarifas de importação.

${ }^{22}$ Sobre o debate siderúrgico nessa década e sobre a concessão a Wigg e Medeiros em particular, bem como sobre a reação que suscitou, ver BARROS, Gustavo. O problema siderúrgico nacional na Primeira República, op. cit., cap. 3.

${ }^{23}$ SILVA, Edmundo de Macedo Soares e. Relatório sobre exportação de minérios de ferro e organização de uma nova usina siderurgica apresentado pelo major Edmundo de Macedo Soares e Silva, 1939. CPDOC - EMS pi Soares, E. 1939.07.10, p. 49; Companhia Brasileira de Usinas
} 
dade em torno de 300 mil t/ano. ${ }^{24}$ Sobre isso, Edmundo de Macedo Soares observava: "Aliás, uma usina de 300 mil toneladas não pode ser considerada muito grande; é uma boa usina média". ${ }^{25}$ Ainda assim, isso deixaria a empresa em questão no controle de cerca de $60 \%$ do mercado brasileiro. Essa ideia de complementar o parque produtivo já existente no país com uma única usina, aliás, se materializaria com a constituição da Companhia Siderúrgica Nacional em 1941, cujo plano de produção seria formulado manifestamente a partir desse critério - na expressão do relatório da Comissão Executiva do Plano Siderúrgico Nacional, talvez ainda mais explícita, de "completar a produção do nosso atual parque siderúrgico". ${ }^{26}$ A capacidade de produção programada para a usina de Volta Redonda pela Comissão Executiva era, não surpreendentemente, de $300 \mathrm{mil} \mathrm{t} / \mathrm{ano}$.

A questão da escala de produção foi efetivamente um dos principais focos de conflito entre os contemporâneos durante o debate siderúrgico e manifestou-se em torno da conhecida polarização entre a "grande siderurgia" e a "pequena siderurgia" ou, mais explicitamente, do ponto de vista daqueles que observavam o problema antes da criação da Companhia Siderúrgica Nacional, "a nossa pequena siderurgia". A discussão sobre a escala de produção, nestes termos, estava ainda diretamente associada a uma determina-

Metallurgicas. Memorial apresentado pela Companhia Brasileira de Usinas Metallurgicas ao Conselho Technico de Economia e Finanças em 31 de maio de 1938. Rio de Janeiro: Typ. do Jornal do Commercio, Rodrigues \& Cia, 1938, p. 4-7, e anexos 2 a 4. Sobre a evolução da capacidade produtiva do setor ver BARROS, Gustavo. O desenvolvimento do setor siderúrgico brasileiro entre 1900 e 1940: Criação de empresas e evolução da capacidade produtiva, op. cit.

${ }^{24}$ Ver, por exemplo, SILVA, Edmundo de Macedo Soares e. Exportação de minérios e siderurgia. Exposição ao Conselho Técnico de Economia e Finanças em 27-V-938, AN-35, lata 507, 1939, p. 32-33, 36, 39, 55; e Idem. Relatório sobre exportação de minérios de ferro..., op. cit., CPDOC EMS pi Soares, E. 1939.07.10, p. 11, 30, 32. Nesses trabalhos, os planos de produção das usinas propostas por Macedo Soares visavam a construção de uma usina para atender praticamente a totalidade das importações correntes, ainda que com expansões futuras já previstas. Visto de outra forma, a usina estava sendo dimensionada para atender o "consumo aparente - produção doméstica", isto é, complementar o parque produtivo existente. Sobre outras propostas no período ver Conselho Técnico de Economia e Finanças do Ministério da Fazenda. A grande siderurgia e a exportação de minério de ferro brasileiro em larga escala. Rio de Janeiro, 1938; e Conselho Federal de Comércio Exterior. Dez anos de atividade. Rio de Janeiro: Imprensa Nacional, 1944.

${ }^{25}$ SILVA, Edmundo de Macedo Soares e. Exportação de minérios e siderurgia, op. cit., AN-35, lata 507, 1939, p. 20.

26 “Fixado o dimensionamento da usina, tal como está enunciado na 'Memória' anexa, o programa de produção foi estabelecido com o objetivo de instalar-se uma usina siderúrgica que vem completar a atual produção nacional. (...) O problema foi encarado tecnicamente, como devia ser, visando-se obter uma produção barata que virá completar a produção do nosso atual parque siderúrgico". Comissão Executiva do Plano Siderúrgico Nacional. Relatório, op. cit., p. xi, ver também p. vii, 3-9. 
da escolha tecnológica quanto ao agente redutor (à época frequentemente chamado de "combustível") mais apropriado para a produção siderúrgica no país. As usinas siderúrgicas existentes no país no período usavam todas o carvão vegetal como agente redutor, o que impedia a construção de altosfornos maiores, em função da menor resistência à compressão do carvão vegetal. A "grande siderurgia" utilizaria como agente redutor o coque, produzido a partir do carvão mineral, o que permitiria o emprego de altos-fornos maiores. Ou seja, a dimensão mais visível de toda essa discussão sobre tecnologia e escala de produção no período esteve basicamente vinculada à primeira etapa de produção siderúrgica, a redução do minério de ferro no alto-forno para a produção de ferro-gusa. Contudo, se de fato havia uma aspecto técnico e econômico nessa discussão, essa era uma disputa essencialmente política, no plano federativo, na medida em que essa escolha tecnológica, dada a disposição geográfica dos insumos produtivos requeridos, tinha implicações diretas e conhecidas sobre a localização mais adequada para a produção siderúrgica. ${ }^{27}$

A historiografia, não sem razão, incorporou esse contraponto entre a "grande" e a "pequena" siderurgia como uma dimensão central de suas interpretações sobre o debate siderúrgico. Contudo, tomou isso como um problema sobretudo técnico e econômico e, na falta de informações mais detalhadas e sistemáticas sobre a composição da demanda, deixou de observar que os problemas mais críticos associados à escala de produção siderúrgica no país estavam ligados à etapa final de produção - a laminação - e não à redução do minério em ferro-gusa, ou no tamanho dos altos-fornos. ${ }^{28}$

De fato, como vimos acima, a proposta de complementar o parque produtivo existente no país com uma única usina, que veio a se concretizar com Volta Redonda, representava uma concessão feita à escala de produção, priorizando as economias de escala em relação à competição no mercado interno. Contudo, mesmo isso não colocava a usina planejada em condições de atender propriamente toda a diversidade da demanda doméstica, em função do descompasso entre consumo doméstico e a escala de produção econo-

\footnotetext{
${ }^{27}$ Para uma discussão sobre essa articulação entre a escolha tecnológica e a localização da(s) usina(s) siderúrgica(s) visada(s) no debate ver BARROS, Gustavo. O problema siderúrgico nacional na Primeira República, op. cit., especialmente as Considerações finais.

${ }^{28}$ Ver, por exemplo, SUZIGAN, Wilson. Indústria brasileira: Origem e desenvolvimento, op. cit., p. 256-278; BAER, Werner. The development of the Brazilian steel industry, op. cit.; WIRTH, John D. The politics of Brazilian development, 1930-1954, op. cit.; RADY, Donald E. Volta Redonda: A steel mill comes to a Brazilian coffee plantation, op. cit.; e PELÁEZ, Carlos Manuel. História da industrialização brasileira..., op. cit.
} 
micamente adequada para produtos laminados individuais. Com efeito, se tomarmos os programas de produção propostos por Edmundo de Macedo Soares e Silva em 1938 e 1939 como os antecessores mais imediatos do que viria a ser a usina de Volta Redonda, ${ }^{29}$ observaremos que ela quase ficou sem uma seção de chapas por este motivo. Durante as discussões no Conselho Técnico de Economia e Finanças, em 1938, Macedo Soares foi categórico a respeito. O país importava uma média anual de "apenas (...) 22.600 [toneladas] de chapas simples, o que é muito pouco para compensar a instalação, no momento, dos laminadores para esse serviço". ${ }^{30}$ Se o governo tivesse um programa naval e de construção de vagões e se fosse ampliada a indústria de caldeiraria no país "teríamos vasto campo a explorar para as chapas". Contudo, esse consumo não existia correntemente, "precisa[va] ser criado". Em 1939, ao ser enviado pelo ministro da Viação Mendonça Lima à Europa e aos EUA para tratar de questões associadas à exportação de minério de ferro e à organização de uma nova usina siderúrgica, a questão das chapas ainda o preocupava. ${ }^{31}$ De fato, predominava no país o ceticismo quanto à possibilidade de fabricação de apenas 50 mil t de chapas por ano, que era o que então se projetava que o mercado brasileiro comportaria. Do ponto de vista técnico, o problema consistia em que a aquisição de um trem laminador esboçador - máquina que prepara os esboços chatos para chapas (os slab-blooms, com seção transversal retangular) - dedicado apenas à produção dessa pequena quantidade de chapas seria claramente pouco econômico. A usina já precisaria contar, de qualquer forma, com um trem laminador esboçador para os esboços para perfis (os blooms, com seção transversal quadrada ou próxima disso). Mas o volume de perfis requerido era maior. Um trem laminador esboçador era, ao mesmo tempo, um equipamento de custo bastante elevado e de alta capacidade de produção. Macedo Soares estimava o custo desse laminador em $£ 300.000$, o que correspondia a em torno de $7 \%$ dos gastos totais a serem realizados no exterior para a construção da

\footnotetext{
${ }^{29}$ Ver nota 24, acima. Macedo Soares veio a ser efetivamente o responsável pela elaboração do programa de produção da usina de Volta Redonda. Comissão Executiva do Plano Siderúrgico Nacional. Relatório, op. cit., p. 3-37.

${ }^{30}$ SILVA, Edmundo de Macedo Soares e. Exportação de minérios e siderurgia, op. cit., AN-35, lata 507, 1939, p. 11

31 SILVA, Edmundo de Macedo Soares e. Relatório sobre exportação de minérios de ferro e organização de uma nova usina siderurgica..., op. cit., CPDOC - EMS pi Soares, E. 1939.07.10.
} 
usina inteira. ${ }^{32}$ Cada trem esboçador tinha capacidade para produzir entre 1.500 e 2.000 t/24h. Em suma, adquirir um esboçador só para chapas, para produzir 150 t/24h, "seria mau emprego para uma grande soma". Mas as visitas técnicas e os contatos realizados na Europa haviam lhe permitido encontrar uma boa solução intermediária. A firma alemã Sack, de Düsseldorf, havia recentemente fornecido a uma usina inglesa um trem esboçador capaz de produzir, alternadamente, tanto esboços para perfis (com dimensões entre 7 x 7 pol a 5 x 5 pol) quanto esboços para chapas (com dimensões entre 16 x 4 pol a 12 x 2 pol). Com um esboçador desse tipo, sugeria Macedo Soares, seria possível à usina trabalhar por dois meses no ano preparando os esboços para chapas, e o restante do tempo preparando os esboços para perfis. Portanto, na ausência dessa solução técnica viabilizada pela Sack, com um trem esboçador que permitia o uso alternado para esboços para perfis e esboços para chapas, possivelmente Volta Redonda não incluiria, ao menos inicialmente, a produção de chapas. De fato, a aquisição de um equipamento desse custo para ser utilizado em 10\% ou menos da sua capacidade de produção não se justificava. E mesmo nesse uso alternado do trem esboçador, o equipamento ainda estaria operando com elevado grau de ociosidade. Segundo Macedo Soares, o esboçador seria capaz de absorver nada menos que a triplicação da produção de chapas, com pequenos ajustes operacionais.

Em outras palavras, o problema de escala mais grave que se colocava frente à solução do "problema siderúrgico nacional" era menos de limite do seu tamanho agregado global com relação à escala necessária à produção econômica de ferro-gusa e mais da pequena dimensão da demanda por produtos laminados individuais, vale dizer, da estrutura da demanda mais do que do seu tamanho. ${ }^{33}$ Questão que ficou praticamente ausente da historiografia sobre o tema.

Esses problemas associados à insuficiência do mercado brasileiro para dar vazão à produção doméstica em escalas mais econômicas eram ainda agravados pela falta de padronização dos produtos fabricados e consumidos

\footnotetext{
${ }^{32}$ Macedo Soares havia solicitado orçamentos para a Brassert e para a Demag, cujos valores totais se aproximavam bastante, e previam ambos gastos no exterior de em torno de $£ 4,2$ milhões.

33 Sobre essa questão, ver ainda Comissão Executiva do Plano Siderúrgico Nacional. Relatório, op. cit., especialmente "Relatório dos engenheiros-consultores Arthur G. McKee $\mathcal{E}$ Co., de Cleveland, Ohio, E.U., sôbre os estudos da Comissão Executiva do Plano Siderúrgico Nacional para a instalação de uma usina siderúrgica no Brasil", p. 108-109; e "Memória sôbre a organização de uma usina siderúrgica no Brasil (relator: tte. cel. E. Macedo Soares e Silva)", p. 31-32.
} 
no país, o que gerava uma fragmentação adicional do mercado em variedades de produtos similares, mas não compatíveis ou substituíveis entre si. ${ }^{34}$

Portanto, se é certo que o parque produtivo siderúrgico doméstico tinha limitações concretas, quantitativas e qualitativas, para o adequado atendimento da demanda. Por outro lado, se consideradas a sua dimensão absoluta, o seu fraco crescimento ao longo do período e a sua diversificação, o mercado brasileiro impunha os seus limites no que diz respeito à escala de produção siderúrgica que era capaz de absorver.

\section{A restrição externa}

Se há bons motivos para considerarmos a evolução do consumo aparente extrassetorial de produtos siderúrgicos como o melhor indicador objetivo disponível da demanda por esses produtos e os picos do consumo aparente como o melhor indicador da dimensão desse mercado no período em análise, por outro lado, não podemos deixar de discutir algumas de suas limitações. Não só porque a questão tem importância metodológica para a nossa análise, mas também porque é apenas tendo claros esses limites que podemos entender mais precisamente como os contemporâneos se basearam em dados de consumo aparente para obter medidas práticas da variável de interesse.

De fato, a forma como os autores contemporâneos viam o problema sofreu uma evolução ao longo das mais de três décadas do debate siderúrgico, sobretudo no que diz respeito à importância das restrições de ordem cambial ou, mais especificamente, da importância da ausência de restrições às importações para o adequado suprimento da demanda interna de produtos siderúrgicos. Já apontamos acima o quão fundamental era a oferta externa para o suprimento da demanda interna nesse setor ao longo do período, e isso apesar de todo o desenvolvimento que experimentou a produção doméstica. Do ponto de vista das estimativas da dimensão do mercado doméstico, a contrapartida disso é que o reconhecimento de que as importações estavam sujeitas a restrições externas, de origem propriamente cambial ou por restrições da oferta externa, introduz uma cunha no uso do consumo

\footnotetext{
${ }^{34}$ Essa questão preocupou, por exemplo, a Comissão Nacional de Siderurgia e Juarez Távora. Relatório final da Comissão Nacional de Siderurgia, [jul./1933]. Boletim do Serviço Geologico e Mineralogico do Brasil, n 75, 1935, p. 170; e TAVORA, Juarez. O contrato da Itabira Iron Ore Co. Ltd. em face dos interesses da economia nacional e do problema da siderurgia brasileira. Mineração e Metallurgia, vol. 2, nº 10, Rio de Janeiro, nov.-dez. 1937, p. 263.
} 
aparente corrente como medida direta do tamanho do mercado doméstico. Afinal, se a produção doméstica é limitada e as importações estavam sujeitas a algum tipo de restrição, cumpre concluir que as necessidades domésticas, nessas circunstâncias, poderiam não estar sendo plenamente atendidas. Isto é, que o consumo aparente corrente poderia ser, em alguma medida, menor do que o tamanho do mercado.

Além disso, cabe ainda observarmos que, a despeito da relativa estabilidade do tamanho do mercado de produtos siderúrgicos, a importância econômica do setor crescia. Por um lado, a participação da produção siderúrgica doméstica no produto ampliou-se ao longo do período. De fato, o setor siderúrgico cresceu a taxas bastante elevadas - 20,4\% a. a. em média entre 1919 e 1940 - claramente superiores às da economia como um todo e mesmo superiores às do setor industrial em seu conjunto. Esse processo de expansão foi acompanhado de uma correspondente queda nos coeficientes de importação de produtos siderúrgicos. No caso dos laminados que, como vimos, compunham a maior parte da demanda, o coeficiente de importação em valor caiu de 100\% em 1919 para 76,1\% em 1940. ${ }^{35}$

Por outro lado, e mais importante do ponto de vista da análise sendo aqui conduzida, apesar do esforço substitutivo em andamento, a pressão das importações siderúrgicas seguia montando. De fato, a participação do valor das importações de produtos siderúrgicos no valor nas importações totais, em meio a oscilações, mostrava uma visível tendência de crescimento ao longo do período, como podemos notar no gráfico 4. Como vemos, a participação dos produtos siderúrgicos no valor das importações totais fora de menos de 3\% em 1901, atingindo pouco mais de 8\% no pico de importações de 1913. Na década de 1930, em contrapartida, uma vez a economia emergida da crise, as importações de produtos siderúrgicos nunca responderam por menos de 8\% do valor das importações totais no período 1934 a 1941, atingindo por vezes picos próximos dos 11\%.

\footnotetext{
35 Para uma discussão detalhada do processo de crescimento e substituição de importações do setor no período, incluindo uma discussão sobre a evolução dos coeficientes de importação e um exame do crescimento da produção siderúrgica doméstica em confronto com o restante do setor industrial, ver BARROS, Gustavo. O desenvolvimento do setor siderúrgico brasileiro entre 1900 e 1940: Crescimento e substituição de importações. Estudos Econômicos, vol. 45, n. 1, jan.-mar. 2015.
} 


\section{Gráfico 4}

Participação dos produtos siderúrgicos no valor das importações totais (1901-1947)

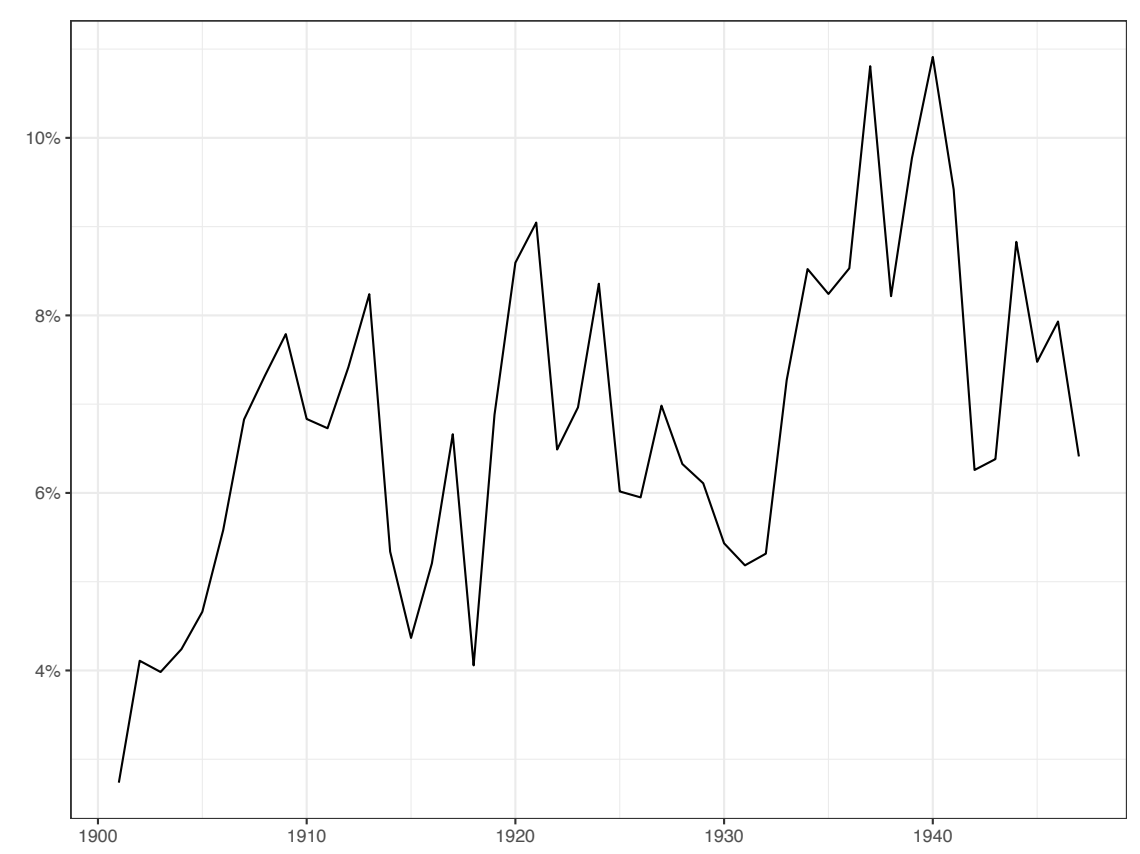

Fonte: Calculado a partir de dados de importação de produtos siderúrgicos na tabela A-4, no apêndice, e dados das importações totais em BARROS, Gustavo. O problema siderúrgico nacional na Primeira República. Tese de doutorado, Departamento de Economia, FEA-USP, São Paulo, 2011, p. 215-216.

O reconhecimento pelos contemporâneos da importância da restrição externa para o problema siderúrgico foi algo que foi ganhando consistência ao longo do período. Concretamente, uma maior clareza a esse respeito só transparece nas fontes contemporâneas no decorrer da década de 1930. Por exemplo, o relatório final da Comissão Nacional de Siderurgia de 1933 é um caso claro de um reconhecimento mais incisivo do papel da restrição externa para o "problema":

A média anual das importações brasileiras de produtos siderúrgicos, durante o quinquênio 1926-1930, foi de 453.498 toneladas, no valor de 560.958:246\$000. (...)

O valor médio das nossas importações totais, durante o mesmo quinquênio, foi de 3.109.030:000\$000; os produtos siderúrgicos representaram assim 18,4\% dessa importância. É a maior parcela das nossas importações; só o trigo e os combustíveis e lubrificantes com, aproximadamente, 415.302:400\$000 e 365.278:000\$000 respectivamente dela se aproximam. 
Produtos siderúrgicos, trigo e combustíveis e lubrificantes constituem cerca de 50\% do valor das importações do Brasil. São os problemas básicos da nossa economia, de que figura, em primeiro lugar, a "siderurgia".36

No início da década de 1940, a Comissão Executiva do Plano Siderúrgico Nacional retomaria a questão, enfatizando que essa participação havia passado de 18,4\% no quinquênio 1926-1930 para 29,6\% no quadriênio 1935-1938. ${ }^{37}$

Outra faceta da questão são as limitações dos dados de consumo aparente para a estimativa da demanda, em função das restrições cambiais e, mesmo, para a estimativa do tamanho do mercado. Em 1938, Francisco Campos, em relatório a Getúlio Vargas sobre a Itabira Iron Ore Co., ao comentar a estimativa do tamanho do mercado siderúrgico doméstico da Comissão Nacional de Siderurgia, articulava com clareza o problema: "o nosso consumo, limitado pelas nossas disponibilidades no estrangeiro, não poderia corresponder, evidentemente, às nossas necessidades efetivas, - éramos forçados a um consumo inferior às nossas exigências". ${ }^{38}$ No ano seguinte, Edmundo de Macedo Soares e Silva, em relatório apresentado ao Ministério da Viação, elaborava o problema de forma similar:

O consumo do País (produção nacional mais importação) é de cerca de 450.000 t/ano. Esse consumo corresponde ao que o País pode, atualmente, produzir e adquirir no estrangeiro; ele não corresponde às necessidades; essas são muito maiores e podem ser avaliadas, segundo estudos feitos cuidadosamente, em cerca de 600.000 t (....39

Ao final da década de 1930, portanto, pelo menos nos círculos especializados, reconhecia-se explicitamente tanto a importância da restrição externa na definição do problema siderúrgico nacional como a insuficiência do uso do consumo (aparente) como indicador das necessidades de produtos siderúrgicos do país. Ainda que os acontecimentos e a experiência tenham levado os envolvidos na discussão a essa decantação conceitual da questão,

${ }^{36}$ Comissão Nacional de Siderurgia. [Estudo sobre o problema siderúrgico], 22/jun/1933. Boletim do Serviço Geologico e Mineralogico do Brasil, nº 75, 1935, p. 151-71. A citação é da p. 152.

${ }^{37}$ Comissão Executiva do Plano Siderúrgico Nacional. Relatório, op. cit., p. 8. Evidentemente, nessas cifras, ambas as comissões estão considerando um escopo consideravelmente mais abrangente de "importações de produtos siderúrgicos" do que o que utilizamos neste trabalho.

${ }^{38}$ CAMPOS, Francisco. Itabira Iron Ore Co., Rio de Janeiro 14/4/1938, CPDOC - GV confid 1938.04.14, p. 12-3.

39 SILVA, Edmundo de Macedo Soares e. Relatório sobre exportação de minérios de ferro..., op. cit., CPDOC - EMS pi Soares, E. 1939.07.10, p. 49. 
de certa forma, ao menos implicitamente, esses aspectos do problema já faziam parte desde cedo das considerações dos contemporâneos em suas estimativas de mercado de forma algo difusa. O uso recorrente dos picos de consumo aparente nas estimativas do tamanho do mercado doméstico, que observamos acima, é testemunho desse fato.

Mas a restrição externa não era tampouco a única limitação à adequada estimativa da capacidade de absorção potencial de produtos siderúrgicos do mercado brasileiro. Francisco Campos, por exemplo, é enfático a esse respeito. Além de apontar que a consideração de anos de crise por parte da Comissão Siderúrgica Nacional implicava uma subestimativa da "nossa capacidade de consumo", como acabamos de observar, ele enfatizava que a estimativa da Comissão desconsiderava ainda outro elemento essencial, a questão das necessidades futuras da economia, para além das correntes. ${ }^{40}$

Isso, aliás, nos traz a uma questão interessante, na medida em que os contemporâneos não adotaram uma perspectiva de longo prazo ao dimensionar o mercado, como as séries disponíveis neste artigo permitem. Pois, apesar disso, era muito frequente que os contemporâneos enfatizassem a tendência de crescimento do mercado de produtos siderúrgicos doméstico. ${ }^{41}$ Mais raramente, alguns arriscavam projeções para prazo mais longo. ${ }^{42} \mathrm{O}$ que se pode inferir do exame dessas projeções é que, em que pese o comportamento efetivo do tamanho do mercado ao longo do debate siderúrgico, a perspectiva dos contemporâneos encontrava claramente espaço para certo otimismo quanto ao setor e para assumir uma tendência de crescimento desse mercado. Não se tratava propriamente de uma dissonância cognitiva. $\mathrm{O}$ fato apontado nesse artigo de que tanto o tamanho do mercado de produtos siderúrgicos quanto a percepção dos contemporâneos sobre o tamanho des-

\footnotetext{
${ }^{40}$ CAMPOS, Francisco. Itabira Iron Ore Co., op. cit., CPDOC - GV confid 1938.04.14, p. 12-3.

${ }^{41}$ Ver as observações da tabela A-1 do apêndice.

${ }^{42}$ Ver, por exemplo, BRAGA, Cincinato. Projecto n. 263 - 1919, Fixa a despeza do Ministerio da Agricultura, Industria e Commercio para o exercicio de 1920, 15/8/1919. Diario do Congresso Nacional, ano XXX, n. 99, 2/9/1919, p. 1914-17; Julian Kennedy, Sahlin \& Co. Limited., Engineers. Proposal for Brazilian Iron $\&$ Steel Industry projected by Messrs. Carlos Wigg and Trajano S. V. de Medeiros, setembro de 1911, CPDOC - EMS d 1911.09.00, doc I-1, p. 25-28; Indústria siderúrgica no Brasil. Relatório conjunto das Comissões Brasileira e Americana, 20/10/1939. In: SILVA, Edmundo de Macedo Soares e. O ferro na história e na economia do Brasil, op. cit., p. XXXIX; SILVA, Raul Ribeiro da. Industria siderurgica e exportação de minerio de ferro: Estudo, projecto e proposta, apresentados ao governo federal. Rio de Janeiro, 1938, p. 42; BRAGA, Cincinato. Magnos problemas econômicos de São Paulo. $2^{a}$ edição. São Paulo: Zenith, 1924 [1ª edição, 1921], p. 254; Comissão Executiva do Plano Siderúrgico Nacional. Relatório, op. cit., p. 5-9.
} 
se mercado praticamente não cresceram nas mais de três décadas ao longo das quais o debate siderúrgico se desenrolou não deve nos levar à conclusão de que esse mercado não tinha potencial de crescimento. Uma composição entre a restrição externa e a redução do ritmo da construção ferroviária pode, a meu ver, dar conta desse arrefecimento prolongado do crescimento do mercado doméstico de produtos siderúrgicos ao longo dessas décadas, ${ }^{43}$ sem necessariamente estabelecer uma tendência a prazo ainda mais longo. De fato, em retrospecto, o crescimento do setor no período pós-Segunda Guerra testemunha esse potencial. A crescente internalização da produção do setor e a continuidade do processo de industrialização levariam o consumo aparente de laminados em 1960 a 2,1 milhões de toneladas e a produção doméstica de laminados em 1967 a 2,9 milhões de toneladas. ${ }^{44}$

Em suma, a despeito desse otimismo com o potencial do mercado no longo prazo, reconhecia-se que a restrição externa resultava numa eventual compressão do consumo aparente de produtos siderúrgicos, com relação ao que se daria na sua ausência. Se isso de fato impõe limitações e nos obriga a qualificações no uso das séries de consumo aparente extrassetorial aqui apresentadas para fins de estimação da demanda corrente e da dimensão do mercado de produtos siderúrgicos à época, na prática é também difícil substituí-las nesse papel. Pois qualquer outra estimativa de demanda ou de mercado recairá, necessariamente, no requisito de realizar uma estimativa contrafactual de qual teria sido esse consumo na ausência da restrição externa. Diante disso, o expediente de avaliar o potencial do mercado doméstico a partir dos anos de pico do consumo aparente, introduzido e sancionado pelos contemporâneos, parece ser ainda a melhor alternativa prática.

\section{Considerações finais}

Este artigo passou em revista a demanda brasileira por produtos siderúrgicos no período entre 1901 e 1940, tendo examinado distintos aspectos desse objeto: i) sua dimensão, tanto em quantidade, como em valor, como em participação no valor das importações; ii) sua composição; e iii) sua evolução no tempo ao longo do período. Na medida em que a insuficiência da oferta interna e os inconvenientes da oferta externa para atender essa demanda

\footnotetext{
43 Contudo, uma avaliação formal da proposição é de difícil realização, uma vez que envolveria uma estimativa de qual teria sido o consumo aparente na ausência da restrição externa.

${ }^{44}$ BAER, Werner. The development of the Brazilian steel industry, op. cit., p. 85.
} 
constituíam a essência mesma do "problema siderúrgico nacional", que foi objeto de um longo debate entre o final da década de 1900 e o início da década de 1940, dedicamos especial atenção a como os contemporâneos conceberam essa dimensão material do problema. Para tanto, fizemos uso de ampla base de fontes primárias, incluindo diversas propostas e intervenções contemporâneas que procuravam estimar a dimensão do mercado doméstico desses produtos e também dados de importação e exportação compilados a partir de dados brutos desagregados previamente indisponíveis na historiografia.

A partir desse conjunto de fontes, pudemos observar que, ao longo das pouco mais de três décadas durante as quais se desenrolou o debate siderúrgico no Brasil, a principal medida disponível da dimensão do mercado de produtos siderúrgicos doméstico, o consumo aparente, oscilou bastante ao sabor da conjuntura do setor externo, mas os seus picos, que representam talvez o melhor indicador do potencial do mercado, apresentaram certa estabilidade. As estimativas contemporâneas da dimensão do mercado, apesar da grande dispersão, também refletiam esse comportamento dos picos de consumo aparente.

Por outro lado, em paralelo com essa relativa estabilidade quantitativa do tamanho do mercado, a demanda por produtos siderúrgicos se diversificava e, globalmente, esses produtos também ampliavam sua participação no valor total das importações. Essa diversificação respondia também ao desenvolvimento da economia brasileira em geral e ao processo de industrialização em particular, na medida em que a composição das importações e do consumo de produtos siderúrgicos, especialmente o de laminados, evoluía ao longo do período no sentido de uma maior participação de produtos com usos mais propriamente industriais, em detrimento de outros, como trilhos e arame. Além disso, a dimensão absoluta do mercado, o seu fraco crescimento ao longo do período e a sua diversificação conjuntamente impunham certas restrições quanto ao que seria possível produzir no país em escala minimamente econômica, sobretudo no que diz respeito a produtos laminados individuais.

Ademais, foi marcante a importância da restrição externa na definição dos contornos do mercado siderúrgico brasileiro ao longo do período e, portanto, também no que se entende, e se entendia então, por "problema siderúrgico nacional". A restrição externa claramente pesou sobre a evolução do consumo de produtos siderúrgicos no período tendo em vista tanto a frequência quanto a força com que se apresentou no período em análise, tanto mais se consideradas a importância da oferta externa para o suprimento da demanda doméstica por produtos siderúrgicos e a significativa participação destes na pauta global de importações. A relevância dessa questão transparece inclusive numa evolução do pensamento sobre o problema siderúrgico 
nacional ao longo do período, tornando as formulações a respeito cada vez mais claras e precisas e, eventualmente, assumindo mesmo a centralidade na definição do problema.

Por fim, cumpre reconhecer que essa importância da restrição externa implica em certas limitações para o uso do consumo aparente como indicador da demanda e da dimensão do mercado interno. Contudo, embora os dados aqui apresentados mereçam essas qualificações e a análise com base neles deva levar isso em consideração, eles claramente constituem as medidas mais adequadas das variáveis de interesse, entre as objetivamente disponíveis.

\section{Referências bibliográficas}

\section{Fontes primárias}

Arquivo Nacional, RJ (AN)

- Fundo do Conselho Nacional de Economia (AN - 1U)

- $\quad$ Fundo do Gabinete Civil da Presidência da República (AN - 35)

- Coleção Paulo de Assis Ribeiro (AN - S7)

Centro de Pesquisa e Documentação de História Contemporânea do Brasil, RJ (CPDOC)

- Edmundo de Macedo Soares (CPDOC - EMS)

- Getúlio Vargas (CPDOC - GV)

- Horta Barbosa (CPDOC - HB)

- $\quad$ Luiz Simões Lopes (CPDOC - LSL)

\section{Publicações seriadas}

Comércio Exterior do Brasil, vários números [anos abrangidos (ano de publicação)].

- Serviço de Estatistica Commercial. Importação geral, 1901 (s.d.).

- Serviço de Estatistica Commercial. Importação e exportação, movimento maritimo, cambial e do café, 1903 (1905), 1904 (1906).

- Ministerio da Fazenda, Serviço de Estatistica Commercial. Importação e exportação, movimento maritimo, cambial e do café, 1905 (1907), 1906 (1907), 1907 (1909), 1908 (1909), 1909 (1911).

- Ministerio da Fazenda, Directoria de Estatistica Commercial. Commercio Exterior do Brasil, 1910-1914 (s.d.), 1913-1918 (1921).

- Ministerio da Fazenda, Directoria de Estatistica Commercial. Commercio Exterior do Brasil, Resumo por mercadorias, movimento maritimo, movimento bancario, 1912-1913 (1914), 1914-1915 (1916), 1915-1919 (1920), 19181922 (1923), 1919-1923 (1924), 1920-1924 (1925), 1921-1925 (1926), 1922-1926 (1927), 1924-1928 (1929), 1928-1929 (1930), 1929-1930 (1931), 1930-1931 (1932). 
- Departamento Nacional de Estatistica (Ministerio do Trabalho, Industria e Commercio). Commercio Exterior do Brasil, resumo por mercadorias, 1931-1932(1933).

- Directoria de Estatistica Economica e Financeira do Thesouro Nacional (Ministerio da Fazenda). Commercio Exterior do Brasil, resumo por mercadorias, 1929-1933 (1934), 1930-1934 (1935), 1932-1936 (1937).

- Serviço de Estatística Econômica e Financeira do Tesouro Nacional (Ministério da Fazenda), Comércio Exterior do Brasil, importação, exportação, 1937-1938 (1941).

- Serviço de Estatística Econômica e Financeira do Tesouro Nacional (Ministério da Fazenda). Comércio Exterior do Brasil, resumo por mercadorias, 1939 (1940), 1940 (1941), 1941 (1942).

- Serviço deEstatística Econômica e Financeira(Ministério da Fazenda, Tesouro Nacional). Comércio Exterior do Brasil, por mercadorias, 1941-1942(1944), 1942-1943 (1947), 1943-1944 ([1947]), 1944-1945 (1948), 1945-1946 (1948), 1946-1947 (1950).

Boletim do Serviço Geologico e Mineralogico do Brasil, Ministerio da Agricultura, Industria e Commercio, Rio de Janeiro.

- Informações sobre a industria siderurgica pelo Dr. Gonzaga de Campos, $\mathrm{n}^{\circ} 2,1922$.

- $\quad$ Relatório final da Comissão Nacional de Siderurgia, nº 75, 1935.

Diario do Congresso Nacional

- Acesso em: <http://www2.camara.gov.br/ $\rightarrow$ Documentos e Pesquisa $\rightarrow$ Publicações e Estudos $\rightarrow$ Diários do Congresso Nacional $>$

Diario do Poder Legislativo

- Acesso em: <http://www2.camara.gov.br/ $\rightarrow$ Documentos e Pesquisa $\rightarrow$ Publicações e Estudos $\rightarrow$ Diários da Câmara dos Deputados $>$

\section{Publicações}

AGUIAR, Francisco M. de Souza. A industria siderurgica: Relatorio apresentado ao exmo. sr. presidente da Republica pelo general F. M. de Souza Aguiar. Rio de Janeiro: Imprensa Nacional, 1910.

BAER, Werner. The development of the Brazilian steel industry. Nashville, TN: Vanderbilt University Press, 1969.

BAER, Werner. The steel industry. In: BERGSMAN, Joel. Brazil: Industrialization and trade policies. Londres: Oxford University Press, 1970, p. 191-221.

BARROS, Gustavo. O problema siderúrgico nacional na Primeira República. Tese de doutorado, Departamento de Economia, FEA-USP, São Paulo, 2011.

. O desenvolvimento do setor siderúrgico brasileiro entre 1900 e 1940: Criação de empresas e evolução da capacidade produtiva. Revista de História Econômica e Economia Regional Aplicada (Heera), vol. 8, n. 14, Juiz de Fora:UFJF, jan.-jun. 2013, p. 9-32.

Discurso e contexto: política siderúrgica no primeiro governo Vargas (1930-1937), 2014. Disponível em:<https://mpra.ub.uni-muenchen.de/57656/>. 
O desenvolvimento do setor siderúrgico brasileiro entre 1900 e 1940: Crescimento e substituição de importações. Estudos Econômicos, vol. 45, n. 1, jan.-mar. 2015, p. 153-183. Disponível em: <http://www.revistas.usp.br/ee/ article/view/69070>. doi: http://dx.doi.org/10.1590/0101-4161201545153gbs.

BASTOS, Humberto. A conquista siderúrgica no Brasil: Crônica e interpretação econômica das empresas e indivíduos, nacionais e estrangeiros, que participaram da exploração dos recursos minerais do desenvolvimento nacional. São Paulo: Livraria Martins Editora, 1959.

BATISTA, Felipe Alvarenga; BARBOSA, Lidiany Silva; GODOY, Marcelo Magalhães. Transportes, modernização e formação regional - Subsídios à história da era ferroviária em Minas Gerais, 1870-1940. Revista de História Regional, vol. 17, n. 1, 2012, p. 162-203. Disponível em: <http://www.revistas2.uepg.br/index.php/ rhr/article/view/3538>. doi: http://dx.doi.org/10.5212/Rev.Hist.Reg.v.17i1.0007.

BRAGA, Cincinato. Magnos problemas econômicos de São Paulo. $2^{\text {a }}$ edição. São Paulo: Zenith, 1924 [1 ${ }^{\mathrm{a}}$ edição, 1921].

CALLAGHAN, William Stuart. Obstacles to industrialization: the iron and steel industry in Brazil during the Old Republic. Ph.D. diss., University of Texas at Austin, 1981.

CALÓGERAS, João Pandiá. As minas do Brasil e sua legislação, vol. 2. Rio de Janeiro: Imprensa Nacional, 1905.

CARVALHO, Elysio de. Brasil, potencia mundial: Inquerito sobre a industria siderurgica no Brasil. Rio de Janeiro: Monitor Mercantil, 1919.

Comissão Executiva do Plano Siderúrgico Nacional. Relatório. Rio de Janeiro, 1940-1941.

Companhia Brasileira de Usinas Metallurgicas. Memorial apresentado pela Companhia Brasileira de Usinas Metallurgicas ao Conselho Technico de Economia e Finanças em 31 de maio de 1938. Rio de Janeiro: Typ. do Jornal do Commercio, Rodrigues \& Cia, 1938.

Conselho Federal de Comércio Exterior. Dez anos de atividade. Rio de Janeiro: Imprensa Nacional, 1944.

Conselho Técnico de Economia e Finanças do Ministério da Fazenda. A grande siderurgiae a exportação de minério de ferro brasileiro em larga escala: Projétos Raul Ribeiro, Paul H. Denizote "Itabira Iron"; Estudos e conclusões apresentadas ao presidente da República em 27 dejulho de 1938 pelo Conselho Técnico de Economia e Finanças do Ministério da Fazenda. Rio de Janeiro, 1938.

GOMES, Francisco M. História da siderurgia no Brasil. Belo Horizonte: Itatiaia, 1983.

GONSALVES, Alpheu Diniz. O ferro na economia nacional. Rio de Janeiro: Ministério da Agricultura, 1937.

GREENE, William H. Econometric analysis. 5ª edição. Upper Saddle River, NJ: Prentice Hall, 2003.

MARTINS, Luciano. Pouvoir et développement économique: Formation et évolution des structures politiques au Brésil. Paris: Antrophos, 1976.

OLIVEIRA, Clodomiro de. Industria siderurgica. Monographia publicada no $\mathrm{n}^{\circ}$ XIV dos Annaes da Escola de Minas de Ouro Preto. Ouro Preto: Officinas da Casa Mattos, 1914 [1912]. 
Problema siderurgico. Conferência realizada no Centro Academico de Ouro Preto em $1^{\circ}$ de janeiro de 1924. Rio de Janeiro: Typ. do Jornal do Commercio, 1924. AN-35, lata 507, 1924.

A concessão Itabira Iron. Belo Horizonte, 1934.

OLIVEIRA, Euzebio Paulo de. Minerios de ferro e a industria siderurgica. Ministerio da Agricultura, Industria e Commercio, Serviço Geologico e Mineralogico do Brasil. Rio de Janeiro: Pap. Americana, 1930. AN-S7, caixa 208.

Mineral resources of Brazil. Ministerio da Agricultura, Industria e Commercio, Serviço Geologico e Mineralogico do Brasil. Rio de Janeiro: Typ. do Serviço de Informações do Ministerio da Agricultura, 1930. AN-S7, caixa 208.

PELÁEZ, Carlos Manuel. História da industrialização brasileira: Crítica à teoria estruturalista no Brasil. Rio de Janeiro: Apec, 1972.

PIRES DO RIO, José. O nosso problema siderurgico: Parecer do deputado Pires do Rio relativo ao acto do presidente da Republica, de 27 de novembro de 1920, que mandou executar o contracto celebrado em 29 de maio de 1920 entre a União e a Itabira Iron Ore Company Limited, de conformidade com o decreto $\mathrm{n}^{\circ} 14.160$ de 11 de maio de 1920. Rio de Janeiro, 1926.

RADY, Donald E. Volta Redonda: A steel mill comes to a Brazilian coffee plantation, industrial entrepreneurship in a developing economy. Albuquerque, New Mexico: Rio Grande Publ., 1973.

Revisão do contracto da Itabira Iron. Relatório e minuta de contracto organizado pela commissão nomeada de ordem do exmo. sr. dr. Getúlio Vargas, chefe do Governo Provisório, pelo exmo. sr. ministro da Viação, dr. José Américo de Almeida; presidente da Commissão: general Sylvestre Rocha; relator da Commissão: dr. Alcides Lins, 1934. (Relatório da "Comissão dos Onze").

SAES, Flávio Azevedo Marques de. As ferrovias de São Paulo, 1870-1940. São Paulo: Hucitec, 1981.

SENNA, Nelson de. O problema da siderurgia nacional. Discurso pronunciado na Câmara Federal, em sessão do dia 21 de novembro de 1923. Rio de Janeiro: Imp. Nacional, 1924.

Siderurgia Nacional e Exportação de Minério de Ferro. Parecer do Conselho Técnico da Sociedade Mineira de Engenheiros. Revista Mineira de Engenharia, 1938.

SILVA, Edmundo de Macedo Soares e.Oferro na história ena economia do Brasil. Rio de Janeiro: Comissão Executiva Central do Sesquicentenário da Independência do Brasil, 1972.

SILVA, Raul Ribeiro da. O problema da siderurgia no Brasil e o contracto da Itabira Iron Ore Company Limited. Conferência realisada em 16 de agosto de 1922 na Associação dos Empregados no Commercio do Rio de Janeiro. Rio de Janeiro, 1922.

. Industria siderurgica e exportação de minerio de ferro: Estudo, projecto e proposta, apresentados ao governo federal. Rio de Janeiro, 1938. AN-35, lata318, 1938.

SUZIGAN, Wilson. Indústria brasileira:Origem e desenvolvimento. São Paulo: Brasiliense, 1986.

TAVORA, Juarez. O contrato da Itabira Iron Ore Co. Ltd. em face dos interesses da economia nacional e do problema da siderurgia brasileira. Apanhado da conferência realizada pelo ten. cel. Juarez Tavora na Escola Polythecnica do Rio, em 29-III-1937, sob os auspicios do Instituto Brasileiro de Mineração e Metalurgia. Mineração e Metallurgia, n 10, vol. 2, Rio de Janeiro, nov.-dez. 1937, p. 260-272. 
TRINER, Gail D. Mining and the State in Brazilian development. Londres: Pickering $\mathcal{E}$ Chatto Ltd., 2011.

VARGAS, Getulio. A nova política do Brasil, vol. V: O Estado Novo, 10 de novembro de 1937 a 25 de julho de 1938. Rio de Janeiro: Livraria José Olympio Editora, 1938.

WIRTH, John D. The politics of Brazilian development, 1930-1954. Stanford, CA: Stanford University Press, 1970.

Recebido: 09/11/2016 - Aprovado: 19/06/2017 


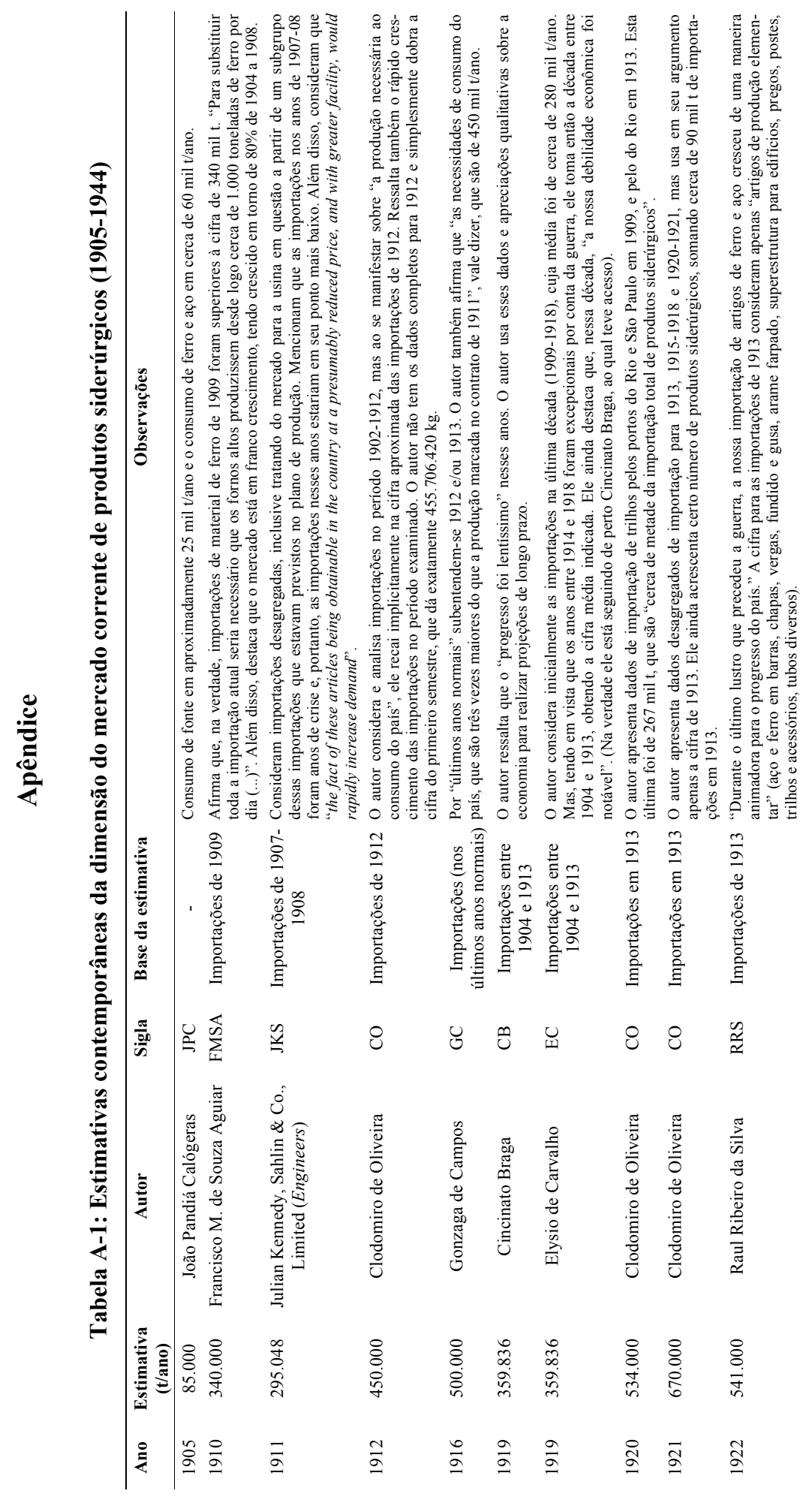




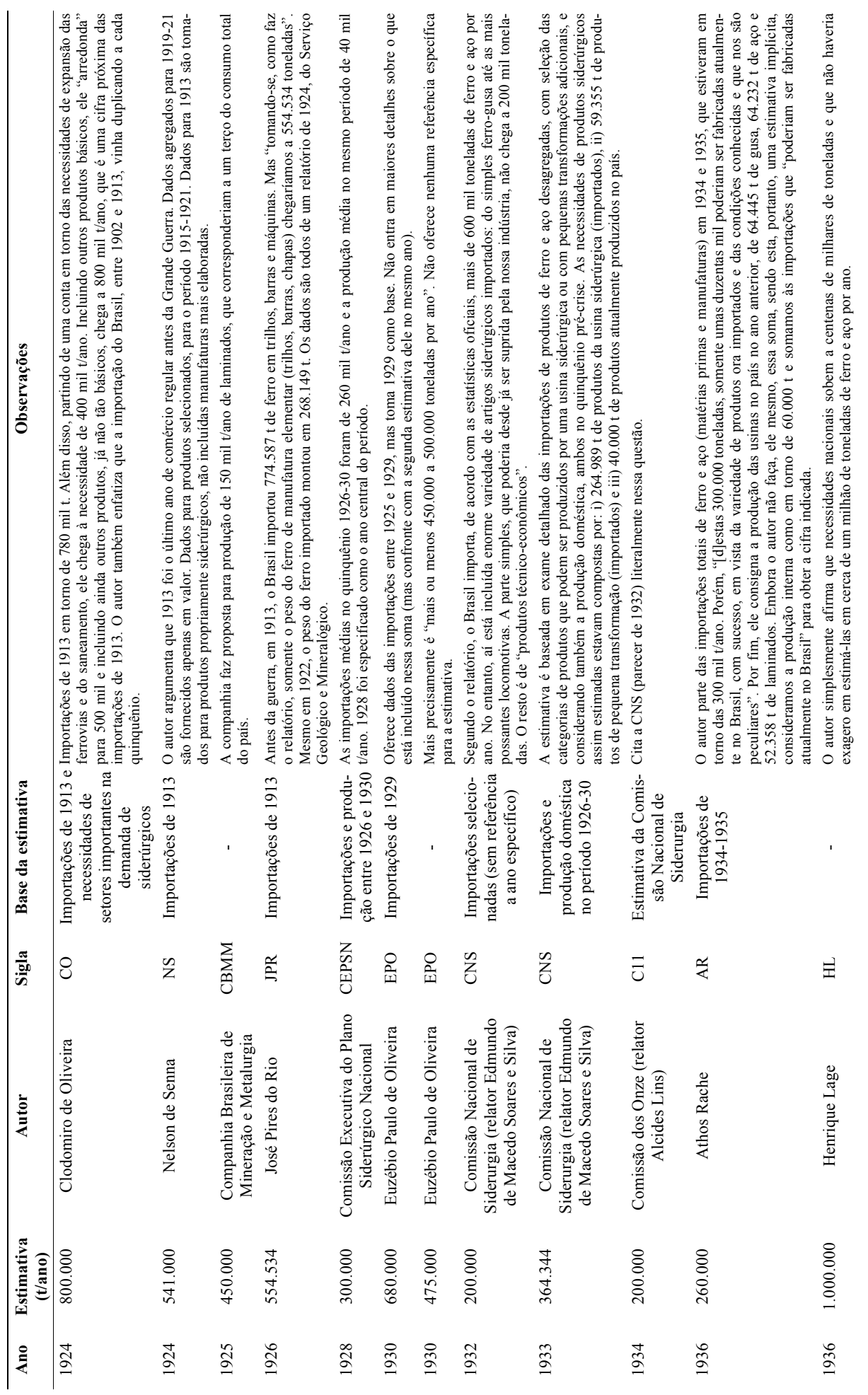




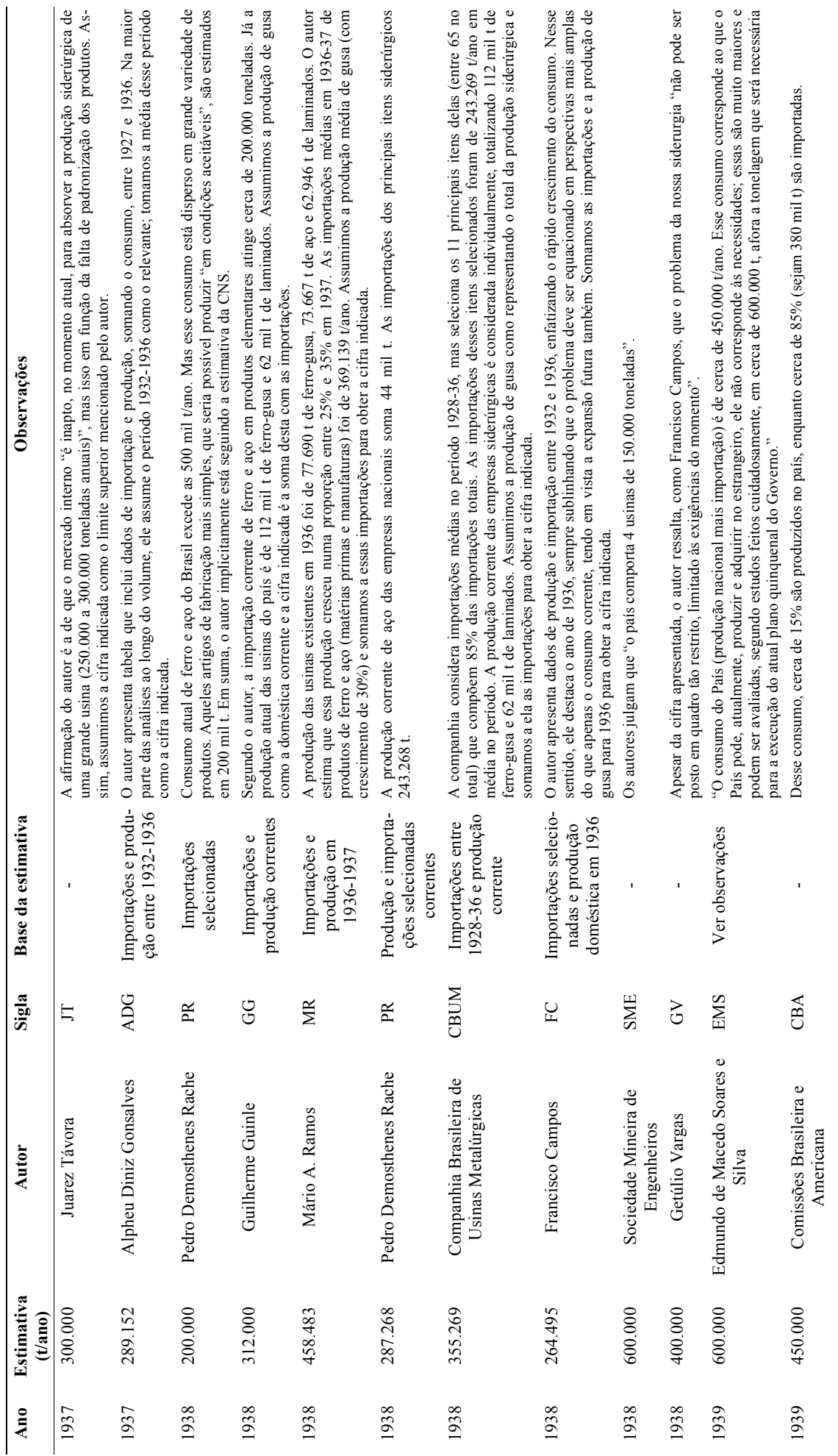




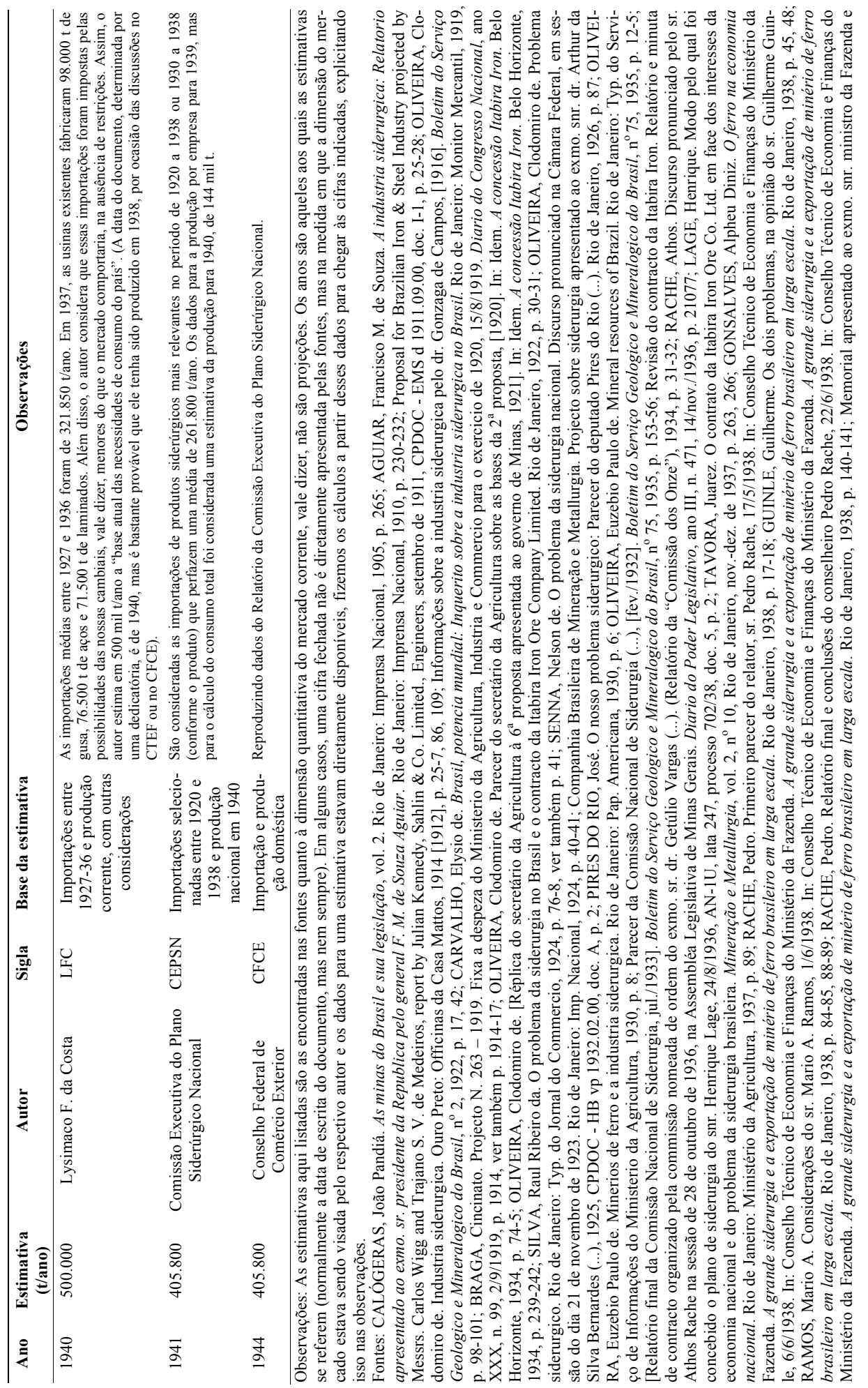


Gustavo Barros

Dimensionando o problema siderúrgico nacional: a demanda por produtos siderúrgicos no Brasil (1901-1940)

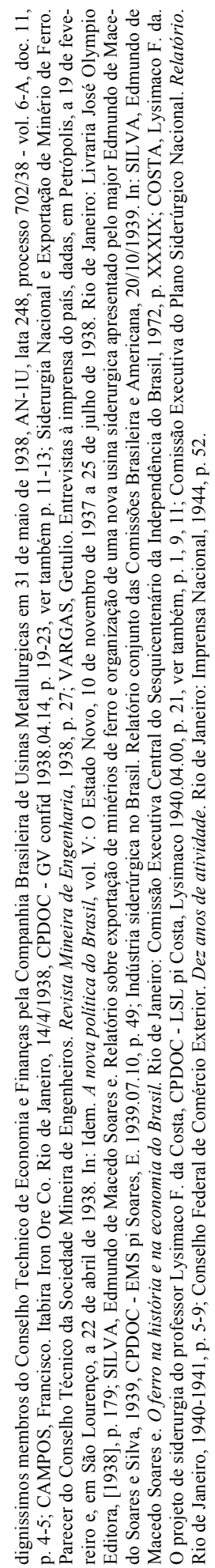


Tabela A-2: Consumo aparente extrassetorial de produtos siderúrgicos (1901-1940)

\begin{tabular}{|c|c|c|c|c|c|c|c|c|}
\hline & \multicolumn{2}{|c|}{ Ferro-gusa ou fundido } & \multicolumn{2}{|c|}{$\begin{array}{l}\text { Ferro e aço brutos } \\
\text { (exceto gusa e fundido) }\end{array}$} & \multicolumn{2}{|c|}{ Laminados } & \multicolumn{2}{|c|}{ Total ferro e aço } \\
\hline & (t) & (mil-réis) & (t) & (mil-réis) & (t) & (mil-réis) & (t) & (mil-réis) \\
\hline 1901 & 2.921 & 247.188 & 0 & 0 & 61.014 & 12.074 .298 & 63.935 & 12.321 .486 \\
\hline 1902 & 4.241 & 338.324 & 0 & 0 & 92.107 & 19.099 .137 & 96.348 & 19.437.461 \\
\hline 1903 & 4.597 & 348.669 & 0 & 0 & 93.286 & 19.105 .881 & 97.883 & 19.454 .550 \\
\hline 1904 & 5.884 & 392.810 & 0 & 0 & 108.934 & 21.428 .586 & 114.818 & 21.821 .396 \\
\hline 1905 & 5.904 & 358.001 & 0 & 0 & 140.358 & 20.913 .533 & 146.262 & 21.271 .534 \\
\hline 1906 & 11.506 & 888.319 & 0 & 0 & 178.850 & 27.070 .774 & 190.356 & 27.959 .093 \\
\hline 1907 & 11.373 & 668.897 & 0 & 0 & 242.909 & 43.450 .011 & 254.282 & 44.118 .908 \\
\hline 1908 & 9.810 & 790.413 & 0 & 0 & 237.330 & 40.851 .606 & 247.140 & 41.642 .019 \\
\hline 1909 & 12.225 & 869.539 & 0 & 0 & 276.060 & 45.423 .518 & 288.285 & 46.293 .057 \\
\hline 1910 & 14.849 & 1.059 .805 & 0 & 0 & 315.376 & 47.859 .426 & 330.226 & 48.919 .231 \\
\hline 1911 & 19.668 & 1.322 .281 & 0 & 0 & 319.379 & 52.245 .627 & 339.047 & 53.567 .908 \\
\hline 1912 & 17.277 & 1.353 .999 & 0 & 0 & 439.968 & 69.413 .532 & 457.244 & 70.767 .531 \\
\hline 1913 & 23.623 & 1.894 .198 & 0 & 0 & 496.274 & 81.350 .861 & 519.898 & 83.245 .059 \\
\hline 1914 & 6.966 & 544.223 & 0 & 0 & 170.542 & 29.580 .641 & 177.508 & 30.124 .864 \\
\hline 1915 & 5.592 & 554.004 & 0 & 0 & 83.580 & 25.177 .791 & 89.172 & 25.731 .795 \\
\hline 1916 & 6.684 & 878.370 & 0 & 0 & 87.014 & 41.820 .185 & 93.698 & 42.698 .555 \\
\hline 1917 & 9.170 & 1.648 .421 & 0 & 0 & 77.083 & 55.429 .153 & 86.253 & 57.077 .574 \\
\hline 1918 & 11.600 & 3.800 .906 & 0 & 0 & 43.763 & 40.033 .829 & 55.363 & 43.834 .735 \\
\hline 1919 & 13.543 & 3.277 .485 & 0 & 0 & 139.508 & 91.014 .786 & 153.050 & 94.292 .271 \\
\hline 1920 & 21.193 & 5.920 .538 & 600 & 1.587 .246 & 263.665 & 176.992 .955 & 285.458 & 184.500 .739 \\
\hline 1921 & 18.250 & 4.433 .832 & 0 & 0 & 185.517 & 152.356 .347 & 203.767 & 156.790 .179 \\
\hline 1922 & 20.736 & 4.866 .886 & 0 & 0 & 182.280 & 106.445 .756 & 203.017 & 111.312 .642 \\
\hline 1923 & 30.284 & 6.982 .548 & 0 & 0 & 192.498 & 155.891 .266 & 222.782 & 162.873 .814 \\
\hline 1924 & 41.529 & 10.249 .399 & 1.348 & 606.420 & 314.386 & 230.505 .113 & 357.262 & 241.360 .932 \\
\hline 1925 & 41.506 & 10.008 .815 & 2.220 & 1.073 .413 & 341.937 & 203.288 .823 & 385.664 & 214.371 .052 \\
\hline 1926 & 34.480 & 8.051 .528 & 2.845 & 1.494 .781 & 338.550 & 164.938 .226 & 375.876 & 174.484 .534 \\
\hline 1927 & 23.916 & 7.172 .033 & 2.318 & 1.295 .358 & 384.892 & 231.173 .173 & 411.126 & 239.640 .564 \\
\hline 1928 & 18.592 & 4.873 .730 & 6.034 & 3.390 .141 & 422.919 & 246.734 .865 & 447.544 & 254.998 .737 \\
\hline 1929 & 26.805 & 6.637 .288 & 7.408 & 4.026 .948 & 390.049 & 231.122 .121 & 424.261 & 241.786 .358 \\
\hline 1930 & 26.649 & 6.713 .136 & 5.685 & 3.093 .862 & 214.228 & 139.950 .676 & 246.562 & 149.757 .674 \\
\hline 1931 & 11.403 & 2.650 .036 & 7.444 & 3.732 .375 & 129.876 & 112.625 .374 & 148.722 & 119.007 .785 \\
\hline 1932 & 5.078 & 1.183 .078 & 11.963 & 5.757 .924 & 141.784 & 107.670 .167 & 158.825 & 114.611 .169 \\
\hline 1933 & 23.052 & 5.863 .302 & 13.065 & 6.039 .719 & 255.717 & 187.684 .219 & 291.834 & 199.587.239 \\
\hline 1934 & 30.853 & 7.859 .315 & 14.653 & 5.719 .017 & 311.766 & 248.379 .370 & 357.272 & 261.957 .702 \\
\hline 1935 & 36.311 & 8.646 .643 & 14.953 & 6.169 .148 & 313.453 & 350.278 .651 & 364.717 & 365.094 .442 \\
\hline 1936 & 46.734 & 14.355 .388 & 16.833 & 10.892 .405 & 348.035 & 411.730 .617 & 411.601 & 436.978 .410 \\
\hline 1937 & 61.992 & 21.701 .295 & 17.093 & 13.275 .239 & 456.560 & 624.935 .268 & 535.644 & 659.911 .802 \\
\hline 1938 & 69.554 & 27.726 .010 & 20.141 & 16.787 .820 & 316.867 & 495.240 .758 & 406.562 & 539.754 .589 \\
\hline
\end{tabular}




\begin{tabular}{|c|c|c|c|c|c|c|c|c|}
\hline & \multicolumn{2}{|c|}{ Ferro-gusa ou fundido } & \multicolumn{2}{|c|}{$\begin{array}{c}\text { Ferro e aço brutos } \\
\text { (exceto gusa e fundido) }\end{array}$} & \multicolumn{2}{|c|}{ Laminados } & \multicolumn{2}{|c|}{ Total ferro e aço } \\
\hline & (t) & (mil-réis) & (t) & (mil-réis) & (t) & (mil-réis) & (t) & (mil-réis) \\
\hline 1939 & 68.442 & 25.496 .655 & 23.964 & 20.318 .925 & 391.374 & 572.449 .874 & 483.781 & 618.265 .454 \\
\hline 1940 & 73.185 & 26.003 .430 & 28.780 & 24.596 .983 & 372.599 & 633.481 .599 & 474.565 & 684.082 .012 \\
\hline
\end{tabular}

Observações: A tentativa de estimar o consumo doméstico envolve algumas especificidades no caso do setor siderúrgico. Isso porque as séries de produção siderúrgica são tipicamente fornecidas para três tipos de produtos principais do setor: ferro-gusa, aço e laminados. Contudo, os dois primeiros não são apenas um "produto" do setor, mas também um importante insumo das etapas posteriores de produção. Vale dizer, tomar três séries de consumo aparente - definidas de forma tradicional como "produção + importação - exportação" - e simplesmente somá-las geraria dupla ou mesmo tripla contagem significativa, na medida em que o setor siderúrgico é um dos grandes consumidores dos seus próprios produtos como bens intermediários. Por esse motivo, utilizamos aqui o consumo aparente "extrassetorial", isto é, o consumo aparente de produtos siderúrgicos feito por outros setores da economia que não o próprio setor siderúrgico (tanto consumo intermediário como demanda final). O consumo aparente extrassetorial de produtos siderúrgicos aqui apresentado foi calculado como "produção + importação exportação - consumo intermediário do setor siderúrgico". Os dados de produção, importação e exportação são conhecidos com precisão a partir das estatísticas oficiais, listadas nas fontes. $\mathrm{O}$ consumo intermediário de produtos siderúrgicos pelo próprio setor foi estimado a partir de informações de produção e aparelhamento produtivo por empresa do setor. Mais especificamente, o consumo intermediário de aço foi estimado a partir da produção de laminados, supondo-se uma perda de $5 \%$. O consumo intermediário de ferro-gusa foi estimado pela produção de aço, deduzida do consumo de sucata pelo setor. Assumimos perda de 5\% para o gusa e 23\% (a taxa média de perda da Fundição de Aço São Paulo entre 1928 e 1932) para sucata na produção de aço. O consumo de sucata foi estimado por empresa, de acordo com o seu consumo médio de sucata entre 1928 e 1932 no Boletim do Serviço Geologico e Mineralogico do Brasil, $\mathrm{n}^{\circ} 75,1935$, p. 130. Essa decomposição do consumo é a mesma que foi utilizada para a estimativa do índice do valor da produção siderúrgica a valores constantes disponível em BARROS, Gustavo. O desenvolvimento do setor siderúrgico brasileiro entre 1900 e 1940: Crescimento e substituição de importações. Estudos Econômicos, vol. 45, n. 1, jan.-mar. 2015, p. 183. A série "Ferro e aço brutos (exceto gusa e fundido)" visa captar o consumo aparente associado à série de produção de "aço", mas foi assim denominada em função da forma como os produtos siderúrgicos eram classificados nas estatísticas de comércio exterior. A esse respeito, ver as observações da tabela A-3.

Fontes: Calculado a partir de dados de produção por empresa em BARROS, Gustavo. O problema siderúrgico nacional na Primeira República. Tese de doutorado, Departamento de Economia, FEA-USP, São Paulo, 2011, p. 202-23, e de dados de importação e exportação nas tabelas A-3, A-4 e A-5. 


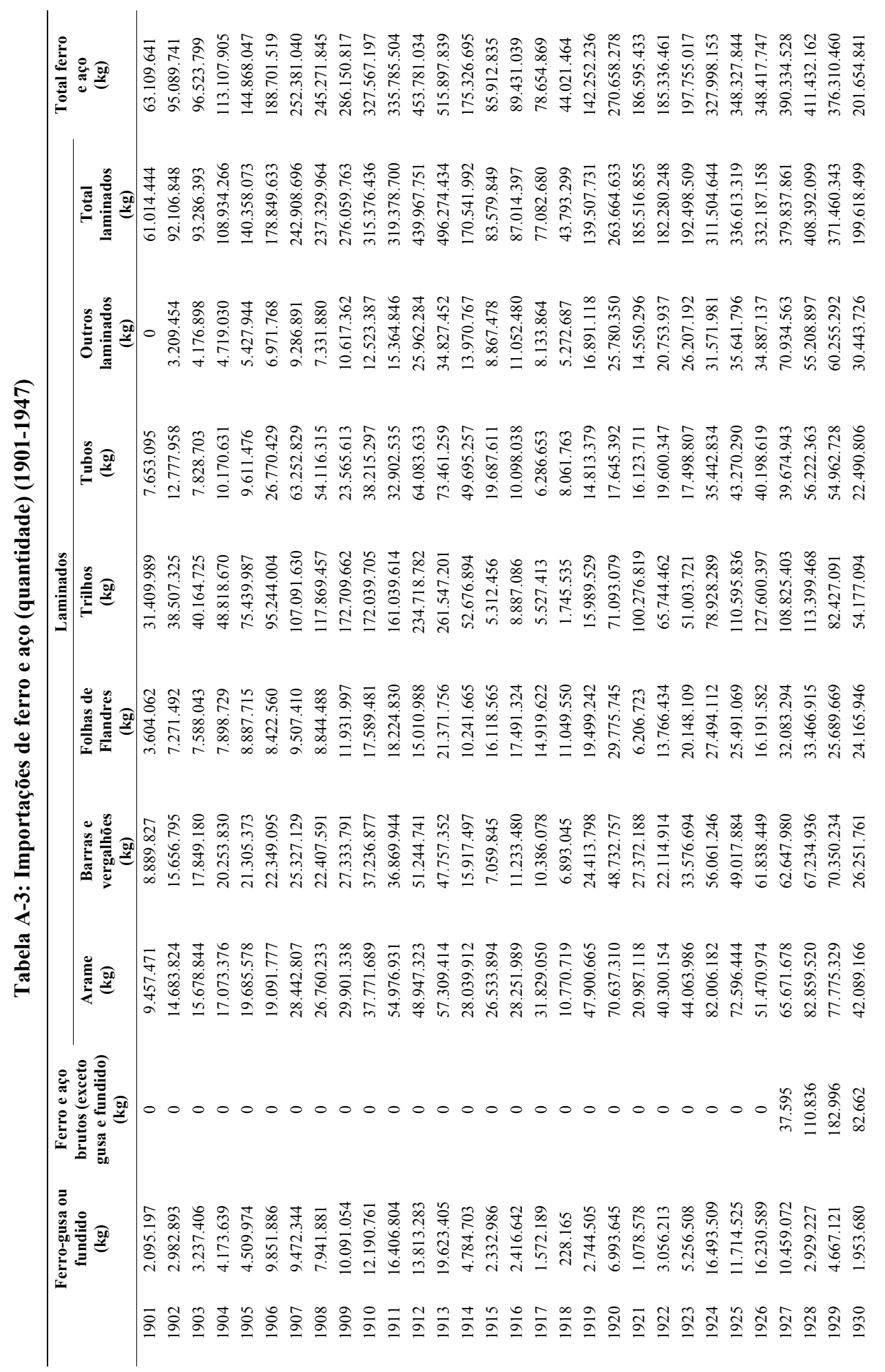




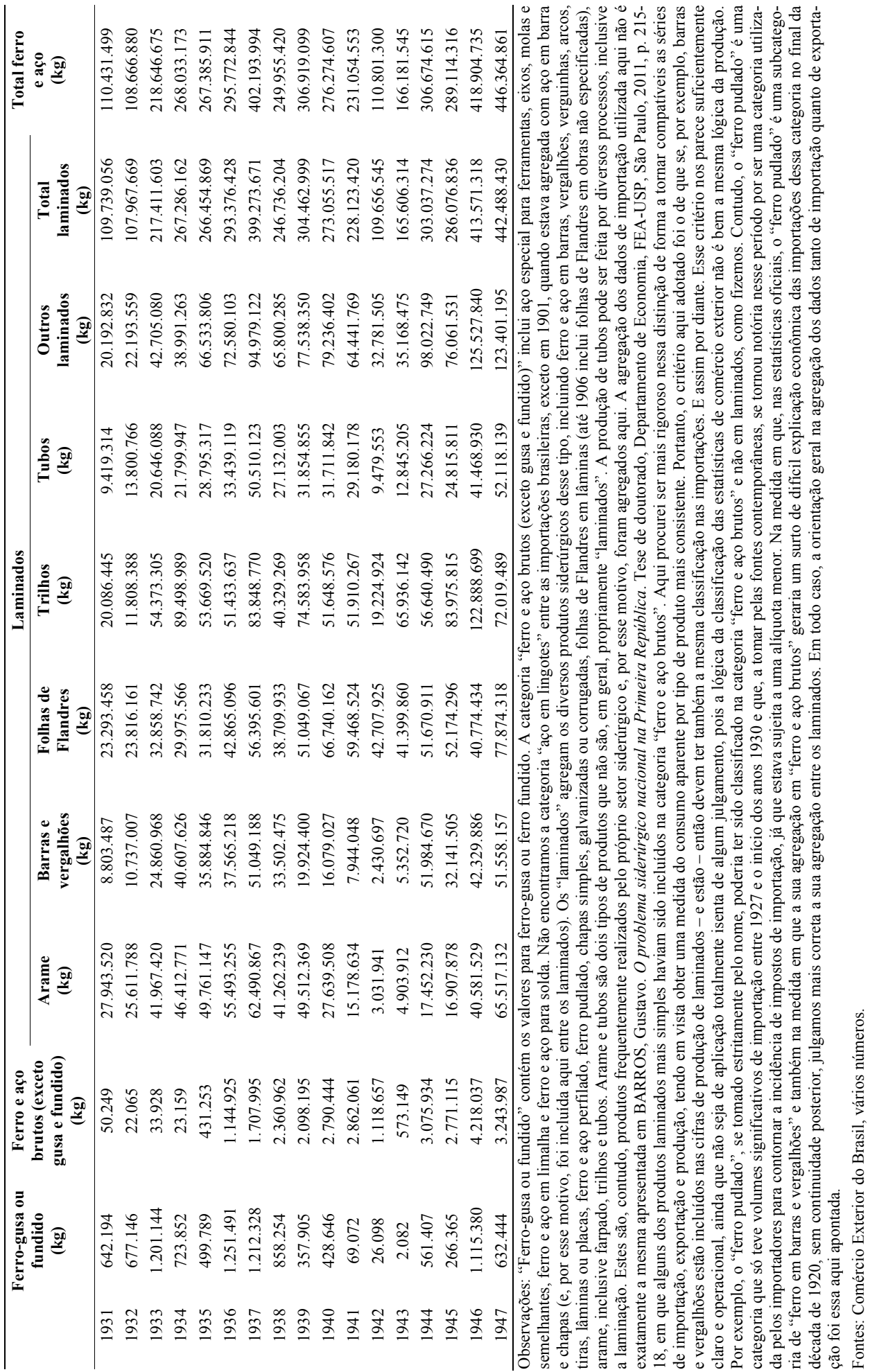




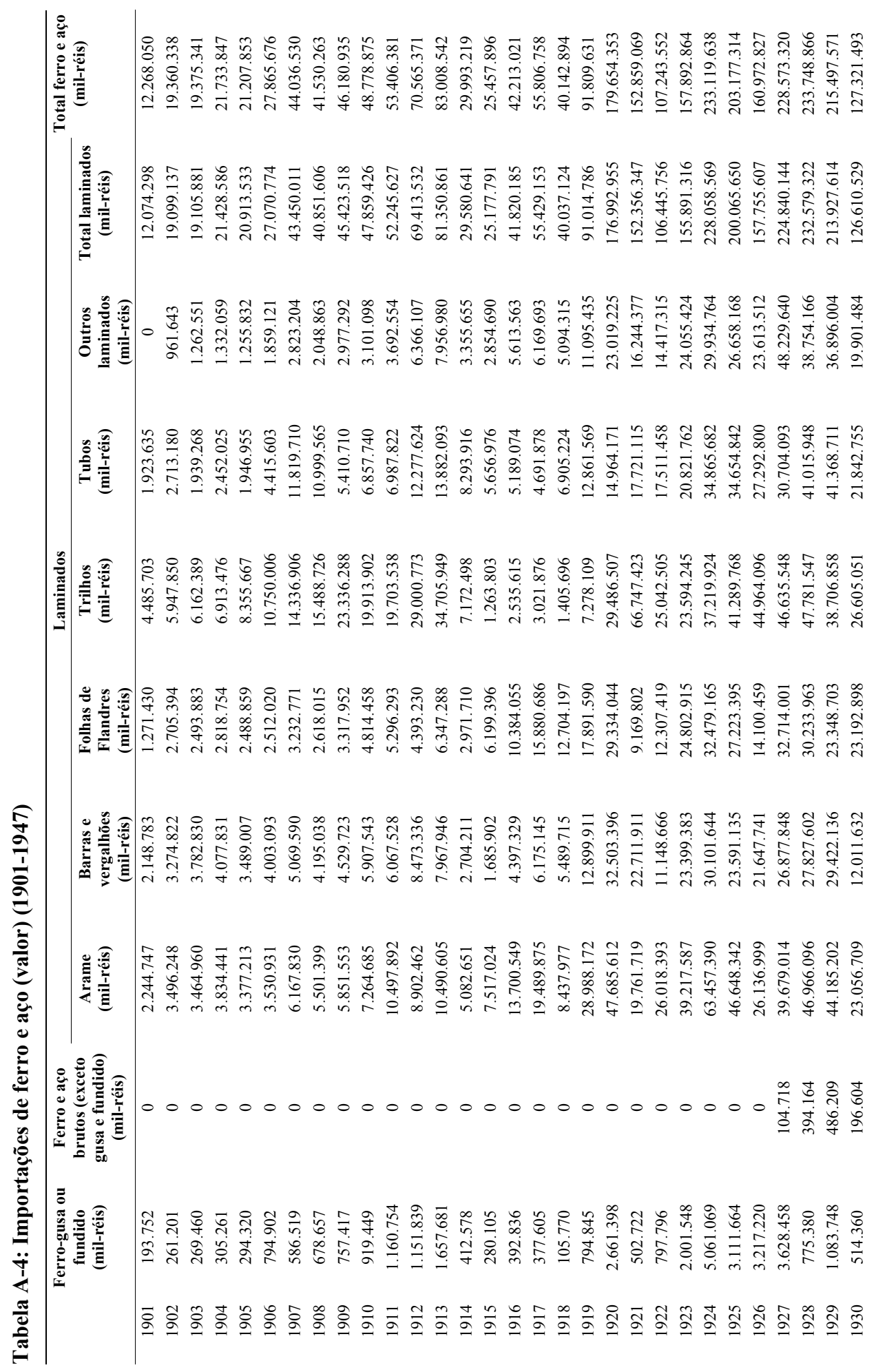




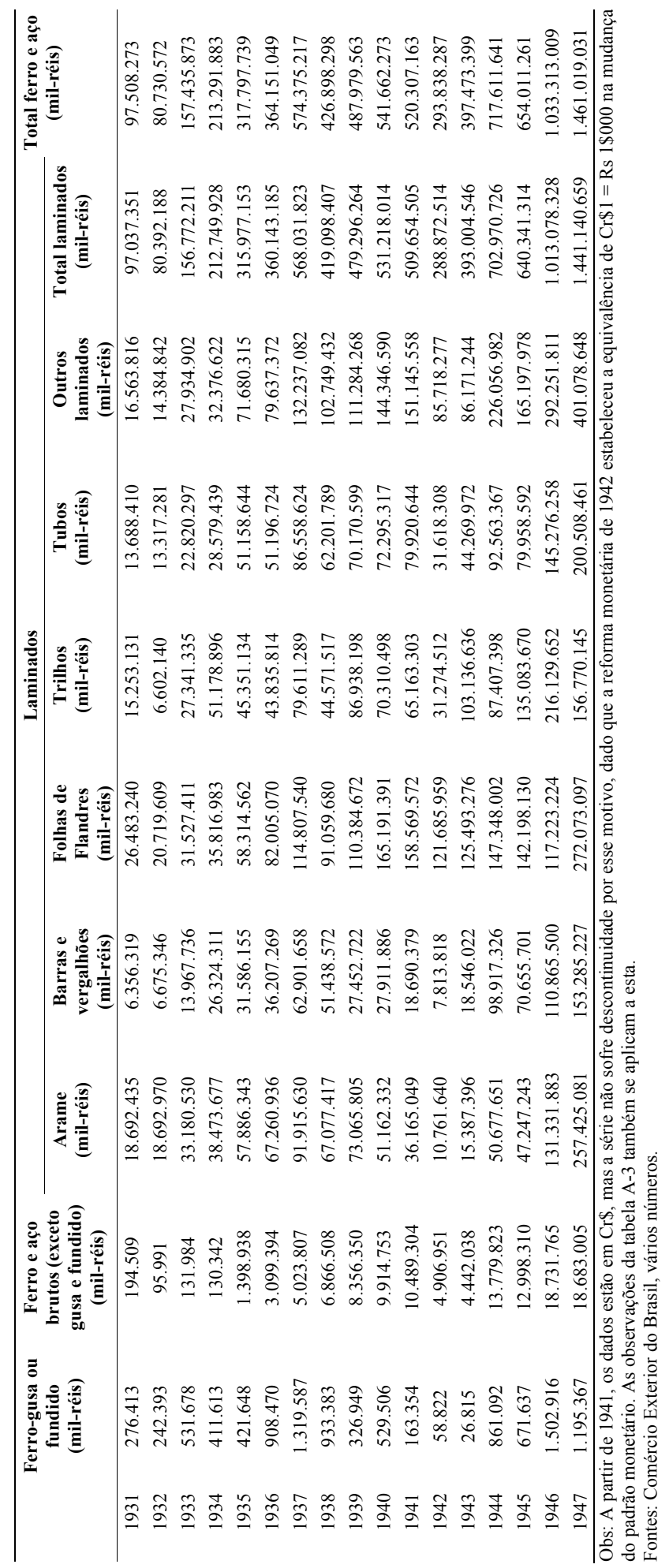


Gustavo Barros

Dimensionando o problema siderúrgico nacional: a demanda por produtos siderúrgicos no Brasil (1901-1940)

Tabela A-5: Exportações de ferro e aço (1901-1947)

\begin{tabular}{|c|c|c|c|c|c|c|}
\hline & \multicolumn{2}{|c|}{ Ferro-gusa ou fundido } & \multicolumn{2}{|c|}{$\begin{array}{c}\text { Ferro e aço brutos } \\
\text { (exceto gusa ou fundido) }\end{array}$} & \multicolumn{2}{|c|}{ Laminados } \\
\hline & (kg) & (mil-réis) & (kg) & (mil-réis) & (kg) & (mil-réis) \\
\hline 1901 & 0 & 0 & 0 & 0 & 0 & 0 \\
\hline 1902 & 0 & 0 & 0 & 0 & 0 & 0 \\
\hline 1903 & 0 & 0 & 0 & 0 & 0 & 0 \\
\hline 1904 & 0 & 0 & 0 & 0 & 0 & 0 \\
\hline 1905 & 0 & 0 & 0 & 0 & 0 & 0 \\
\hline 1906 & 0 & 0 & 0 & 0 & 0 & 0 \\
\hline 1907 & 0 & 0 & 0 & 0 & 0 & 0 \\
\hline 1908 & 0 & 0 & 0 & 0 & 0 & 0 \\
\hline 1909 & 0 & 0 & 0 & 0 & 0 & 0 \\
\hline 1910 & 0 & 0 & 0 & 0 & 0 & 0 \\
\hline 1911 & 0 & 0 & 0 & 0 & 0 & 0 \\
\hline 1912 & 0 & 0 & 0 & 0 & 0 & 0 \\
\hline 1913 & 0 & 0 & 0 & 0 & 0 & 0 \\
\hline 1914 & 0 & 0 & 0 & 0 & 0 & 0 \\
\hline 1915 & 0 & 0 & 0 & 0 & 0 & 0 \\
\hline 1916 & 0 & 0 & 0 & 0 & 0 & 0 \\
\hline 1917 & 50.000 & 15.000 & 0 & 0 & 0 & 0 \\
\hline 1918 & 376.238 & 117.062 & 0 & 0 & 30.180 & 3.295 \\
\hline 1919 & 10.000 & 3.200 & 0 & 0 & 0 & 0 \\
\hline 1920 & 85.420 & 26.410 & 0 & 0 & 0 & 0 \\
\hline 1921 & 346.705 & 98.030 & 0 & 0 & 0 & 0 \\
\hline 1922 & 102.800 & 21.000 & 0 & 0 & 0 & 0 \\
\hline 1923 & 160.000 & 56.400 & 0 & 0 & 40 & 50 \\
\hline 1924 & 0 & 0 & 0 & 0 & 0 & 0 \\
\hline 1925 & 0 & 0 & 0 & 0 & 0 & 0 \\
\hline 1926 & 0 & 0 & 0 & 0 & 0 & 0 \\
\hline 1927 & 0 & 0 & 0 & 0 & 0 & 0 \\
\hline 1928 & 0 & 0 & 0 & 0 & 0 & 0 \\
\hline 1929 & 0 & 0 & 0 & 0 & 0 & 0 \\
\hline 1930 & 0 & 0 & 0 & 0 & 0 & 0 \\
\hline 1931 & 6.390 .000 & 1.496 .558 & 0 & 0 & 0 & 0 \\
\hline 1932 & 3.540 .000 & 744.283 & 0 & 0 & 0 & 0 \\
\hline 1933 & 0 & 0 & 0 & 0 & 0 & 0 \\
\hline 1934 & 0 & 0 & 0 & 0 & 0 & 0 \\
\hline 1935 & 0 & 0 & 0 & 0 & 0 & 0 \\
\hline 1936 & 0 & 0 & 0 & 0 & 8.000 & 4.800 \\
\hline 1937 & 120.850 & 47.445 & 0 & 0 & 0 & 0 \\
\hline
\end{tabular}


rev. hist. (São Paulo), n. 176, a08416, 2017 http://dx.doi.org/10.11606/issn.2316-9141.rh.2017.122711
Gustavo Barros

Dimensionando o problema siderúrgico nacional: a demanda por produtos siderúrgicos no Brasil (1901-1940)

\begin{tabular}{|c|c|c|c|c|c|c|}
\hline & \multicolumn{2}{|c|}{ Ferro-gusa ou fundido } & \multicolumn{2}{|c|}{$\begin{array}{l}\text { Ferro e aço brutos } \\
\text { (exceto gusa ou fundido) }\end{array}$} & \multicolumn{2}{|c|}{ Laminados } \\
\hline & (kg) & (mil-réis) & (kg) & (mil-réis) & (kg) & (mil-réis) \\
\hline 1938 & 2.328 .000 & 746.428 & 0 & 0 & 0 & 0 \\
\hline 1939 & 23.413 .520 & 8.739 .556 & 2.000 & 9.348 & 0 & 0 \\
\hline 1940 & 22.147 .472 & 11.321 .604 & 88.979 & 237.839 & 8.457 .779 & 9.277 .871 \\
\hline 1941 & 34.946 .613 & 20.846 .383 & 635.733 & 2.381 .169 & 25.310 .563 & 38.768 .841 \\
\hline 1942 & 6.135 .662 & 7.275 .305 & 1.671 .000 & 10.174 .100 & 5.925 .100 & 9.895 .448 \\
\hline 1943 & 17.958 .146 & 28.454 .442 & 2.522 .967 & 15.866 .143 & 10.951 .063 & 22.552 .880 \\
\hline 1944 & 4.241 .771 & 6.554 .116 & 1.789 .776 & 11.237 .378 & 10.122 .923 & 27.832 .280 \\
\hline 1945 & 16.832 .965 & 24.985 .856 & 2.558 .345 & 15.627 .362 & 16.235 .594 & 68.834 .580 \\
\hline 1946 & 23.013 .520 & 24.478 .521 & 7.775 & 59.928 & 3.256 .905 & 13.511 .836 \\
\hline 1947 & 29.464 .412 & 41.928 .430 & 38.021 & 234.507 & 2.502 .342 & 10.593 .766 \\
\hline
\end{tabular}

Observações: A partir de 1941, os dados estão em Cr\$, mas a série não sofre descontinuidade por esse motivo, dado que a reforma monetária de 1942 estabeleceu a equivalência de $\mathrm{Cr} \$ 1$ = Rs $1 \$ 000$ na mudança do padrão monetário. "Ferro-gusa ou fundido" contém os valores para ferro-gusa ou ferro fundido. A categoria "ferro e aço brutos (exceto gusa e fundido)" inclui ligas, como ferro manganês, ferro níquel, ferro silício e ferro cromo bem como solda. Os "laminados" agregam ferro e aço em barras, vergalhões, verguinhas, tiras, placas, discos, perfis, tubos, arame liso, farpado, polido e em tela bem como matérias primas de ferro e aço não especificadas. Sobre os critérios gerais de agregação utilizados, ver as observações da tabela A3.

Fontes: Comércio Exterior do Brasil, vários números. 